\title{
Effects of CEO Turnover in Banks: Evidence Using Exogenous Turnovers in Indian Banks
}

\author{
Arkodipta Sarkar, Krishnamurthy Subramanian, \\ and Prasanna Tantri*
}

\begin{abstract}
We examine the effects of chief executive officer (CEO) turnover in banks. Incoming bank CEOs face problems of information asymmetry because banks' operations are opaque and bank risk can change dramatically in a short time. These CEOs may therefore change bank policies to manage their personal risks. Since CEO turnover is usually endogenous, we utilize a setting in which CEO turnover is based solely on retirement age and is thus exogenous to bank performance. Consistent with our thesis, incoming CEOs increase provisioning for future delinquencies and shrink lending. Bank stock prices decline following these changes. Politically motivated lending or ever-greening cannot explain our results.
\end{abstract}

\section{Introduction}

After the recent financial crisis, chief executive officer (CEO) turnover in banks has occupied media headlines. For instance, commenting on the highprofile CEO turnovers in the world's biggest banks in 2015, the Financial Times reported: "In the space of seven months in 2015, a trio of the world's biggest banks, Barclays, Deutsche Bank, and Credit Suisse, all brought new leaders on board. These 'new brooms' face similar challenges in cleaning up their

\footnotetext{
*Sarkar, asarkar@ london.edu, London Business School; Subramanian (corresponding author), krishnamurthy_subramanian@isb.edu, Tantri, prasanna_tantri@isb.edu, Indian School of Business. We thank Paul Malatesta (the editor) and an anonymous referee for their suggestions. We thank Viral Acharya, Sumit Agarwal, Yakov Amihud, Tarun Chordia, Jeffrey Coles, Vidhan Goyal, Sanjay Kallapur, Luc Laeven, Hariom Manchiraju, Danny Miller, Deepak Mohanty (executive director, Reserve Bank of India), Randall Morck, Urjit Patel (governor, Reserve Bank of India), Raghuram Rajan (former governor, Reserve Bank of India), Lakshmanan Shivakumar, Anand Srinivasan, K R Subramanyam, and all the participants of seminars/conferences at the Indian School of Business, Reserve Bank of India, Asian Bureau for Financial and Economics Research, and Midwest Finance Association for helpful comments and suggestions. We also thank the Indian School of Business Center for Analytical Finance for providing the data and the necessary financial assistance for this project. Subramanian thanks the Centre for Advanced Financial Research and Learning (CAFRAL) for research support. We thank Venkatesh Ramamoorthy for excellent research assistance. We also thank Sai Harsha Katuri, Mohan Ramanath, and Padma Priya for assistance with data collection. The usual disclaimer applies.
} 
businesses: cutting costs, reshaping their investment banks, and dealing with a legacy of legal and regulatory transgressions." ${ }^{1}$ Of the top 10 financial firms in the United States (by asset size), 6 experienced CEO turnovers in 2007-2008. ${ }^{2}$ In fact, in this period, financial firms showed higher CEO turnover rates than nonfinancial firms.

Although CEO turnovers represent significant corporate events in general (since CEOs shape key firm policies), CEO turnovers in banks are even more important than those in nonfinancial firms. First, because banks are special (Ashcraft (2003)) and bank financing represents a critical lifeline for credit-constrained firms (Chava and Purnanandam (2011)), changes in banks' operations can create spillover effects for the entire economy. ${ }^{3}$ Second, because banks' operations are inherently opaque (Furfine (2001)) and their risks can change drastically in a short period (Myers and Rajan (1998)), the incoming CEO of a bank faces significant information asymmetry. Finally, as the global financial crisis highlighted, the level of risk-taking in banks can create externalities for the macroeconomy (see Acharya and Richardson (2009a), Fahlenbrach and Stulz (2011)). Yet, little is known about the effects of CEO turnovers in banks. In this study, we fill this gap in the literature by examining these effects.

As the examples of CEO turnover in banks noted previously illustrate, such turnovers are endogenous. This poses a key challenge in studying any related effect. CEO turnover correlates not only with firm performance (see Coughlan and Schmidt (1985), Warner, Watts, and Wruck (1988), Weisbach (1988), Parrino (1997), Denis, Denis, and Sarin (1997), and Kim (1996)) but also with that of the industry and economy (Jenter and Kanaan (2015)). Therefore, industry- or economy-wide shocks cannot offer exogenous variation to study this relationship. Even CEO turnover due to either the passage of state-level anti-takeover laws (Bertrand and Mullainathan (2003)) or banking deregulation (Hubbard and Palia (1995)) would suffer from similar problems. Finally, even voluntary retirements pose identification challenges because they not only depend on firm performance (Liebersohn (2015)) but may also represent forced retirements disguised as voluntary (Schwartz-Ziv and Weisbach (2013)).

To overcome these identification challenges, we use exogenous variation in CEO turnover in Indian government-owned banks (GOBs). The CEOs of GOBs demit office when they reach their retirement age. Crucially, for the purpose of identification, this retirement age is common for all government employees and is set by the government of India. ${ }^{4}$ Naturally, therefore, we find no correlation between turnover and bank performance in the year the CEO exits.

\footnotetext{
${ }^{1}$ See http://www.ft.com/cms/s/0/6f4fea28-aa24-11e5-955c-1e1d6de94879.html\#ixzz42sbrDM56.

${ }^{2}$ Of Citigroup, Bank of America, JPMorgan Chase, Morgan Stanley, AIG, Fannie Mae, Merrill Lynch, Goldman Sachs, Freddie Mac, and Wachovia, which were the top 10 banks by asset size, Citigroup, AIG, Federal National Mortgage Association (Fannie Mae), Merrill Lynch, Federal Home Mortgage Corporation (Freddie Mac), and Wachovia experienced CEO turnovers in 2007-2008.

${ }^{3}$ King and Levine (1993), Demirgüç-Kunt and Maksimovic (1998), Rajan and Zingales (1998), and Beck, Demirgüç-Kunt, and Levine (2009) provide cross-country evidence for the macroeconomic effects of bank financing. Jayaratne and Strahan (1996), (1998), Cetorelli and Strahan (2006), and Beck, Levine, and Levkov (2010) provide evidence within the United States.

${ }^{4}$ In our sample, the retirement age for all government servants is 60 .
} 
Theory provides three conflicting predictions about the effects of CEO turnover in banks. The "big-bath" hypothesis posits that the incoming CEO resorts to "window-dressing" accounts in the transitional quarter (Pourciau (1993), Elliott and Shaw (1988), Strong and Meyer (1987), and DeAngelo and DeAngelo (1989)). A lower base and the mean-reverting nature of discretionary accounting adjustments can then enable CEOs to show higher profits during their tenure. The "truth-telling" hypothesis predicts that the incoming CEO implements policies that reveal the actual situation of the firm (Hertzberg, Liberti, and Paravisini (2010)). Such policies may involve terminating ever-greened loans doled out by the outgoing CEO and/or rectifying past underprovisioning. The outgoing CEO may ever-green loans to hide true loan performance or to cover up loans originated either under political influence or with corrupt motives. By revealing the truth, incoming CEOs can signal their abilities as effective monitors. The "personal risk management hypothesis" (Amihud and Lev (1981)) predicts that the incoming CEO increases provisions and reduces lending to minimize personal costs from negative outcomes due to the predecessor's actions.

Under the big-bath hypothesis, purely accounting changes should not affect stock prices. While stock prices should increase if the incoming CEO changes bank policies under the truth-telling hypothesis, stock prices should decline if the CEO makes such changes to reduce personal risk because bank policies that reduce the incoming CEO's personal risks may not add to firm value (Amihud and Lev (1981)).

These conflicting theoretical predictions set the agenda for our empirical analysis. We hand-collect data on CEO retirement dates for each GOB since 2002. Each GOB experienced multiple CEO retirements during this period. Overall, there were 79 CEO turnover events during our sample period. We estimate the hypothesized effects as a generalized difference-in-difference, averaged across these 79 quasi-experiments; a GOB that experiences CEO turnover in a particular quarter forms the treatment group, while the other GOBs that did not experience a CEO turnover in the same quarter form the control group. Because GOBs closely resemble each other, those that did not experience CEO turnover serve as an excellent control group in our setting. ${ }^{5}$ Given exogenous CEO turnover, the difference-in-difference tests estimate the causal effects of CEO turnover.

We report the following findings. First, we find that incoming CEOs increase provisions for bad loans, as measured by the ratio of loan loss provisions (LLPs) to income, by $8.5 \%$ in the first quarter in which they are in charge. We examine LLPs because among the many accounting items relevant in banks, LLPs are most susceptible to manipulation. ${ }^{6}$ However, we find no change in LLP in the outgoing CEO's last quarter.

Second, we examine the association between current LLPs and future nonperforming assets (NPAs) to distinguish between earnings smoothing and

\footnotetext{
5 "Public-sector banks have broadly similar organizational structures and human resource policies. It has been argued that India has too many public-sector banks with similar characteristics" (speech by Dy. Governor of Reserve Bank of India, R. Gandhi, Apr. 22, 2016; see https://www.rbi.org.in/ Scripts/BS_SpeechesView.aspx?Id=999).

${ }^{6}$ For example, Collins, Shackelford, and Wahlen (1995) and Kilic, Lobo, Ranasinghe, and Sivaramakrishnan (2012) show that banks use LLPs to smooth earnings. Ahmed, Billings, Morton, and Stanford-Harris (2002) find evidence that banks use LLPs to manage their capital adequacy.
} 
impounding of information about future NPAs. In general, we find that bank CEOs use LLPs to smooth earnings. However, the increased LLPs in the transitional quarter primarily impounds information about future NPAs, which is inconsistent with the big-bath hypothesis.

Third, we find that loan volume declines by $7.04 \%$ during the transition year. Using unique data on bank-borrower relationships and the characteristics of ever-greened loans documented in the extant literature, we find that the decline in lending is not driven by the incoming CEO terminating ever-greened loans. ${ }^{7}$ Thus, truth-telling by terminating ever-greened loans may not explain our findings.

Fourth, we find that the cumulative 3-day abnormal return around the announcement date of results by the new CEO is $-1.7 \%$, which is statistically significant. Earlier studies show that the stock market reacts positively when the truth is revealed (Beaver, Eger, Ryan, and Wolfson (1989), Elliott, Hanna, and Shaw (1991), Griffin and Wallach (1991), and Wahlen (1994)). Therefore, the evidence is inconsistent with truth-telling by the incoming CEO. The decrease in stock prices also supports the claim that the evidence, when taken together, is consistent with the personal risk management hypothesis.

Fifth, we provide evidence consistent with the hypothesis that incoming CEOs face information asymmetry. Unlike changes under the incoming CEO, we find no evidence of any changes in the last year of the outgoing CEO. This phenomenon is consistent with the hypothesis that the outgoing CEO does not face any information asymmetry. We also find no evidence of any changes in firm policies due to CEO turnover in government-owned nonfinancial firms, which is consistent with information asymmetry being lower in nonfinancial firms than in banks. These placebo tests thus highlight that changes under the incoming CEO most likely originate from the information asymmetry the incoming CEO faces.

Our study focuses on Indian GOBs to overcome the identification challenges posed by the endogeneity of CEO turnover. However, concerns about data quality and peculiarities related to GOBs naturally arise. We note that the bank and year fixed effects control, respectively, for any time-invariant factors specific to a bank as well as factors common across all banks in a year. In fact, because GOBs closely resemble each other, our use of GOBs that did not experience CEO turnover as a control group also alleviates many such concerns, even if they are time-varying. Additionally, any factor that does not vary systematically between the transition quarter and other quarters cannot affect our results.

Nevertheless, in our final set of tests, we ensure that our results do not stem from any peculiarities of GOBs. Specifically, we conduct several tests that ensure data quality in GOBs. We also conduct tests to mitigate concerns that our results are driven by politically motivated lending or ever-greening.

To our knowledge, ours is the first study to examine the effects of CEO turnover in banks. Because CEOs shape key bank policies, and banks play

\footnotetext{
${ }^{7}$ See Peek and Rosengren (2005), Bruche and Llobet (2014), Caballero, Hoshi, and Kashyap (2008), Hoshi and Kashyap (2004), and Rogoff (2002) for studies on the characteristics of ever-greening.
} 
a special role in the economy, it is important to study the impact of CEO turnover in banks. Agency problems in nonfinancial firms are well documented in the finance literature. However, agency problems in financial institutions are only receiving attention in the academic literature since the financial crisis. These problems in banks lead bank CEOs to assume excessive risks (Taylor (2009)) and manage their earnings (Acharya and Richardson (2009b), Huizinga and Laeven (2012)). Agency problems may also increase the risk of bank failure (see Acharya and Richardson (2009a), Fahlenbrach and Stulz (2011)). Our work contributes to this emerging literature by examining the effects of CEO turnover in banks and documenting their economic costs through the effects on overall lending.

The rest of the article proceeds as follows: In the next section (Section II), we discuss the rationale for banks being special. In Section III, we lay down the main hypotheses. Section IV details our empirical strategy, and Section V describes the data. Section VI describes the main findings of this article, and Section VII rules out alternate explanations. Section VIII concludes.

\section{Why Are Banks Special?}

\section{A. Information Asymmetry}

Although information asymmetries plague all sectors, evidence suggests that banks face higher information asymmetry (Furfine (2001)). Loan quality in banks is not readily observable and can be hidden for long periods. This, in turn, manifests for several reasons. First, banks need not disclose information about individual loans. Second, borrower disclosures about private lending arrangements need not include the name of the banks involved. Third, the information regulators obtain by examining banks remains confidential. Fourth, banks can alter the risks underlying their assets more quickly than firms in most nonfinancial industries (Myers and Rajan (1998)) can. Finally, banks can readily hide problems by evergreening their loans. Consistent with such opacity, Morgan and Stiroh (2001) find that bond analysts disagree more over bonds issued by banks than those issued by nonfinancial firms.

\section{B. LLPs Influence Earnings and Risk}

Earnings management in banks is typically measured by the proclivity to make i) discretionary LLPs or ii) discretionary realizations of security gains or losses (Cornett, McNutt, and Tehranian (2006)).

\section{LLPS}

As in nonfinancial firms, banks can use accruals to manage their earnings. LLPs represent one of the most important accrual items in banks (see, e.g., Beaver et al. (1989), Moyer (1990), Scholes, Wilson, and Wolfson (1990), Wahlen (1994), Beatty, Chamberlain, and Magliolo (1995), Beaver and Engel (1996), Kim and Kross (1998), and Liu and Ryan (2006)). LLPs are an expense item in the income statement, reflecting management's current assessment of the likely level of future losses from defaults on outstanding loans. Recording LLPs reduces net income. LLPs are calculated using an incurred loss approach and reflect the expected losses from lending. Several studies find evidence that banks use LLPs 
to manage earnings (Greenawalt and Sinkey (1988), Wahlen (1994), Laeven and Majnoni (2003), and Liu and Ryan (2006)). Thus, LLPs are quite susceptible to manipulation in banks.

A key feature of LLPs, unlike accruals in nonfinancial firms, is that they simultaneously influence bank profitability and bank risk (Bushman and Williams (2012), Beatty and Liao (2011)). Commercial bank regulators specify bank capital based on the bank's risk-weighted assets, which reflect the expected losses on loans. Therefore, bank capital absorbs unexpected losses, defined as negative deviations from the expected losses. Regulators view accumulated LLPs as a type of capital that banks can use to absorb losses. Too high LLPs lower the reported profitability but increase the buffer against unexpected losses. Thus, high LLPs reduce the chance that a bank uses its capital to cover unexpected losses (Laeven and Majnoni (2003)). Conversely, low LLPs increase reported profitability but also increase the chance that a bank must use its capital to cover unexpected losses. Because equity capital is quite costly to raise (Myers and Majluf (1984)), LLPs affect bank risk.

\section{Realized Security Gains and Losses}

In addition to LLPs, bank CEOs exercise discretion in deciding the realization of security gains and losses (Beatty et al. (1995), Beatty, Ke, and Petroni (2002)). Unlike LLPs, security gains and losses are relatively unregulated. Moreover, it is unlikely that auditors, regulators, or shareholders will subsequently take issue with a manager's decision to sell an investment security that happens to increase or decrease earnings. Thus, realized security gains/losses represent a second way that management can manage earnings.

\section{Hypotheses}

Apart from the information asymmetry incoming CEOs face, agency problems due to the CEO's "horizon problem" matter for CEO turnovers because they affect the bank's policies. The CEO's horizon problem arises from the fact that the CEO's decision horizon is shorter than shareholders' investment horizons (Jensen and Smith (2000)). So, CEOs approaching retirement age become more myopic; they place less weight on cash flows occurring after their retirement than on cash flows occurring during their employment (Dechow and Sloan (1991), Mannix and Loewenstein (1994), Buchholtz and Ribbens (1994), Buchholtz, Ribbens, and Houle (2003), Barker and Mueller (2002), and Conyon and Florou (2003)).

As we describe in the Introduction, the predicted effects vary based on the hypothesized effect of CEO turnovers on bank policies. We summarize the various predictions in the following table to enable easy interpretation of our results:

Effect in the Transitional Quarter

LLPS

Correlation of LLPS with future NPAs

Correlation of LLs with earnings before provisions

Correlation of LLPs with earnings after provisions

Lending

Stock prices following first earnings announcement
Hypothesis

\begin{tabular}{ccc}
\multicolumn{3}{c}{ Hypothesis } \\
\hline Big & Truth- & \\
Bath & Telling & Personal Risk \\
$\uparrow$ & $\uparrow$ & Management \\
$\leftrightarrow$ & $\uparrow$ & $\uparrow$ \\
$\uparrow$ & $\leftrightarrow$ & $\leftrightarrow$ \\
$\leftrightarrow$ & $\downarrow$ & $\downarrow$ \\
$\leftrightarrow$ & $\downarrow$ & $\downarrow$ \\
$\leftrightarrow$ & $\uparrow$ & $\downarrow$ \\
\hline
\end{tabular}


Thus, the stock price reaction to the new CEO's first earnings announcement enables us to distinguish between the truth-telling and personal risk management hypotheses.

\section{Empirical Setting}

\section{A. The Indian Banking System}

The banking industry in India includes GOBs, private-sector banks, and foreign banks. GOBs account for $74.2 \%(75.1 \%)$ of all outstanding loans (deposits) in the Indian banking sector. The State Bank of India and its associate banks alone account for $21.8 \%$ (25.2\%) of all outstanding loans (deposits). ${ }^{8}$ Thus, GOBs dominate the Indian banking system.

\section{B. CEO Turnover in GOBs}

In this section, we discuss the retirement and appointment procedures for CEOs of GOBs in India. A CEO of a GOB retires once attaining the age of superannuation. The government of India specifies the age of superannuation for all GOB employees. Since May 1998, this age is fixed at 60. The CEO of a GOB is officially designated as chairman and managing director (CMD) and is both the top executive and chairman of the board. However, for convenience, we refer to the head of a GOB as a CEO in this article.

The procedure for CEO appointment is rule-based, with restrictions applied based on eligibility, tenure, and so on. Seniority (measured as the number of years of service) is given preference over other attributes. All appointments must be cleared by the Central Vigilance Commission (CVC), which is the federal agency in charge of investigating alleged corruption and fraud. The outgoing CEO has no role in the appointment of a new CEO. Moreover, the new appointment is always announced very close to the exit date of the incumbent CEO. Thus, in our setting, whereas outgoing CEOs know when their terms end (because they end on the date of superannuation), incoming CEOs know about their appointments just a month or so before assuming office. Therefore, the predecessor and successor cannot collude to set bank policies.

\section{A Clean Empirical Setting}

CEO exits may be endogenously determined by bank performance (Murphy and Zimmerman (1993)), industry performance, and economic performance (Jenter and Kanaan (2015)). Therefore, industry- or economy-wide shocks cannot offer exogenous variation to study this question. Finally, even voluntary retirements pose identification challenges because they not only depend on firm performance (Liebersohn (2015)) but may also represent forced retirements disguised as voluntary (Schwartz-Ziv and Weisbach (2013)).

An ideal empirical setting to examine the causal effects of CEO turnover is one in which i) outgoing CEOs know the duration of their terms at the bank; that is, CEO turnover is predictable; and ii) CEO turnover is exogenous to bank performance. Following the discussion in Section III, the CEO's horizon problem is

\footnotetext{
${ }^{8}$ See http://www.rbi.org.in/scripts/PublicationsView.aspx?id=15044
} 


\section{FIGURE 1 \\ Clean Identification Provided by Age-Determined CEO Turnover}

Figure 1 depicts how the retirement policy set by the government provides a clean setting for identification.

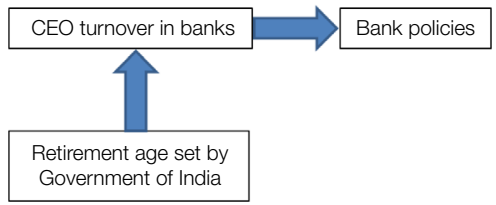

important in order that CEO turnover will affect bank policies. For the costs due to the manager's horizon problem to manifest, an ideal empirical setting must meet the first condition. Thus, we need a setting where CEO turnover is determined by some variable that is uncorrelated with bank performance. Some studies use unpredictable events such as sudden deaths to examine the causes and effects of CEO turnover (see Johnson, Magee, Nagarajan, and Newman (1985), Hayes and Schaefer (1999), and Salas (2010)). However, in these cases, the effects due to the CEO's horizon problem do not manifest.

Our empirical setting, as depicted in Figure 1, satisfies both requirements because CEOs' exits are exogenously determined by a rule that is linked to their ages. Thus, outgoing CEOs know exactly when they will retire. Consequently, all costs arising from the CEO's horizon problem would manifest in our setting. Simultaneously, given age-based CEO exits, CEO turnover in our setting is not related to bank performance.

\section{Data and Proxies}

To obtain data on banks' financial performance, we use the Prowess database maintained by the Centre for Monitoring Indian Economy (CMIE). Prior studies use similar data from Prowess (see Visaria (2009), Lilienfeld-Toal, Mookherjee, and Visaria (2012), Vig (2013), and Gopalan, Mukherjee, and Singh (2016)). We use quarterly financial information on banks. Since complete data are available in Prowess from 2002 onward, we begin our sample from the 2002 calendar year. Our sample ends in the Apr.-June quarter of 2013. Given the 21 GOBs and 46 quarters, the maximum possible number of observations in our sample is 966 $(=21 \times 46)$. Some GOBs were not partially privatized in 2002. Data are not available for bank-quarters where the bank is not listed in the stock markets. Hence, we do not have data for all banks starting from 2002. Specifically, data for 84 bank-quarters are not available. Therefore, we have a maximum of 882 observations at the (bank, quarter) level for LLP, income, and other income statement variables. Information from balance sheets, such as lending and capital adequacy ratio, is available for a smaller sample. Data on LLPs and capital adequacy ratios are available for 757 bank-quarters, data on lending are available for 760 bank-quarters, and data on lending and capital adequacy ratios are available for 732 bank-quarters. Information about NPAs, LLPs, and capital adequacy ratios 
is available for a maximum of 670 bank-quarters. However, as we show later, missing data do not account for our results.

For our tests of the ever-greening of loans, we use data at the firm-quarter level. For each quarter, Prowess provides the names of the banks with which a firm has a banking relationship. These tests employ 44,316 observations at the (borrower, quarter) level.

Since Prowess does not specify the exact date a new CEO joins the bank, we hand-collect data on this from various sources, including press announcements, CEOs' résumés, and company histories. Our sample consists of all 21 GOBs in India. ${ }^{9}$ Table A.1 (in the Supplementary Material) lists all CEO turnovers for each GOB during our sample period. As Table A.1 shows, each GOB experienced multiple CEO turnovers during our sample period. Therefore, we have adequate variation in CEO turnovers within each bank to conduct tests that control for bank fixed effects. Finally, we obtain information regarding the postretirement board memberships of bank CEOs in our sample from Prowess. In Section VI, we perform several tests to address possible concerns about data quality.

\section{A. Defining the Transitional Quarter}

We define the transitional quarter in two ways. As our preferred definition, we define the transitional quarter as the first quarter in which the new CEO assumes charge. For example, if a new CEO assumes charge on the 5th of January, then the January-March quarter is the transitional quarter. We use this definition for all our tests.

As our second definition, we define the transitional quarter as the first quarter in which the incoming CEO announces the bank's results. In the previous example, if the results for the October-December quarter are announced on Jan. 30, then the October-December quarter is the transitional quarter. We use this definition as a robustness check, especially to measure the impact of CEO turnover on accounting measures. The implicit assumption here is that the CEO taking charge before the results are announced is sufficient to influence the earnings estimates.

\section{B. Summary Statistics}

Table 1 presents the summary statistics for our data. We examine the turnover of all CEOs in 21 GOBs in India. The median and mean tenures for CEOs of GOBs is approximately 2.9 years (11.5 quarters) and approximately 3.1 years (12.6 quarters), respectively. For comparison, consider CEO tenure in U.S. firms. Since the 2000s, the average CEO tenure in the United States has been approximately 4 years (Le Breton-Miller and Miller (2006)). Thus, during our sample period, CEO tenure at GOBs is lower by approximately $25 \%$ compared with CEO tenure at U.S. firms.

During our sample period, Indian GOBs maintained a healthy median profitto-income ratio of $12 \%$. These banks' net interest margin is between 3 to $4 \%$, whereas the median LLP-to-income ratio is $11.9 \%$. Indian GOBs have a healthy capital adequacy ratio of $12.79 \%$. The median amount of loans outstanding for all

\footnotetext{
${ }^{9}$ We do not consider the State Bank of India's subsidiaries separately because, as per section 2(bb) of the State Bank of India Act of 1955, the chairman of the State Bank of India is the chairman of all subsidiaries.
} 
TABLE 1

Summary Statistics

\begin{tabular}{|c|c|c|c|}
\hline Variable & Mean & Median & Std. Dev. \\
\hline No. of CEOs per bank & 4.45 & 4 & 1.31 \\
\hline Tenure of CEOs (quarters) & 12.57 & 11.5 & 5.05 \\
\hline LLP-to-income ratio & 0.13 & 0.12 & 0.07 \\
\hline LLP-to-loan ratio & 0.18 & 0.05 & 2.71 \\
\hline Profit-before-provisions-to-income ratio & 0.32 & 0.12 & 5.38 \\
\hline Profit-after-provisions-to-income ratio & 0.12 & 0.12 & 0.059 \\
\hline Advances (in billions of rupees) & $1,014.96$ & 625.77 & $13,222.98$ \\
\hline Net NPAs (in billions of rupees) & 15 & 7.21 & 27.54 \\
\hline
\end{tabular}

the GOBs in a quarter is INR 625.77 billion, which is equivalent to USD 10.46 billion.

\section{Results}

\section{A. Is CEO Turnover Indeed Exogenous?}

We argue in Section IV.B that CEO turnover is driven only by the age of the incumbent. To examine if CEO turnover is indeed exogenous, we run the following regression:

$$
\text { CEO_TURNOVER }_{i t}=\beta_{0}+\beta_{i}+\beta_{t}+\beta_{1} \times x_{i, t-1}+\gamma X_{t}+\varepsilon_{i t},
$$

where CEO_TURNOVER is 1 for 4 quarters preceding the transition quarter, and 0 otherwise. Given the use of lead-lags in this empirical design, we lose some observations in these tests. The term $x_{i, t-1}$ denotes one of the correlates we test for, and $\beta_{i}$ and $\beta_{t}$ denote bank fixed effects and fixed effects for each (year, quarter), respectively. In all regressions, we estimate standard errors clustered by bank to account for possible autocorrelation.

Table 2 presents the results from equation (1). We do not find any significant change in LLPs, NPAs, net profit-to-income ratio, or volume of lending in the 4 quarters preceding the transitional quarter. Thus, it is unlikely that the CEO is replaced due to subpar performance in the quarters preceding the transition. These tests confirm that CEO turnover is indeed exogenous in our setting.

\section{B. Identification Strategy}

Because CEO turnover in GOBs in India is exogenous to bank performance, we can infer the causal effect of CEO turnover on the variables of interest by estimating a difference-in-difference. To clarify, consider the CEO change at the Bank of Baroda in May 2008. Because the Apr.-June quarter of 2008 represents the transitional quarter, we can first estimate the difference in bank policy in the Apr.-June 2008 quarter for the Bank of Baroda vis-à-vis the average in all other quarters. Then, we can estimate the same difference for every other GOB that did not experience a CEO turnover in the Apr.-June 2008 period. Because the government of India owns majority stakes in all GOBs, they closely resemble each other. Thus, a GOB that did not experience CEO turnover serves as an excellent control group in our setting. The difference between these two differences 
TABLE 2

\section{Exogenously Determined Exits of CEOs in Public-Sector Banks}

\begin{tabular}{|c|c|c|c|c|}
\hline \multirow[b]{2}{*}{ Variable } & \multicolumn{4}{|c|}{ CEO_TURNOVER } \\
\hline & 1 & 2 & 3 & 4 \\
\hline LLP-to-income ratio & $\begin{array}{l}-0.337 \\
{[-1.022]}\end{array}$ & & & \\
\hline NPA ratio & & $\begin{array}{l}-0.002 \\
{[-0.482]}\end{array}$ & & \\
\hline Advances (in billions of rupees) & & & $\begin{array}{l}-0.000 \\
{[-0.539]}\end{array}$ & \\
\hline Net profit ratio & & & & $\begin{array}{c}-0.634 \\
{[-1.310]}\end{array}$ \\
\hline $\begin{array}{l}\text { Bank fixed effects } \\
\text { Year and quarter fixed effects }\end{array}$ & $\begin{array}{l}\text { Yes } \\
\text { Yes }\end{array}$ & $\begin{array}{l}\text { Yes } \\
\text { Yes }\end{array}$ & $\begin{array}{l}\text { Yes } \\
\text { Yes }\end{array}$ & $\begin{array}{l}\text { Yes } \\
\text { Yes }\end{array}$ \\
\hline $\begin{array}{l}\text { No. of obs. } \\
\text { No. of banks } \\
\text { Adj. } R^{2}\end{array}$ & $\begin{array}{c}798 \\
21 \\
0.109\end{array}$ & $\begin{array}{c}619 \\
21 \\
0.093\end{array}$ & $\begin{array}{c}684 \\
21 \\
0.098\end{array}$ & $\begin{array}{c}811 \\
21 \\
0.114\end{array}$ \\
\hline
\end{tabular}

provides a causal estimate of the effect of CEO change on bank policies at the Bank of Baroda in Apr.-June 2008. This is because the second difference just described provides an estimate for the counterfactual question: What would have been the change in the Bank of Baroda's policies if the particular CEO change had not occurred in Apr.-June 2008?

While the example considers a single CEO-turnover event at the Bank of Baroda, our sample consists of 79 such exogenous CEO turnovers in 21 GOBs. We estimate the average of the difference-in-differences estimates over each of these events. Our baseline specification to estimate this difference-in-difference is

$$
Y_{i t}=\beta_{0}+\beta_{i}+\beta_{t}+\beta_{1} \times \mathrm{NEW}_{-} \mathrm{CEO}_{i t}+\gamma X+\varepsilon_{i t},
$$

where the dependent variable is an outcome measure for bank $i$ in (year, quarter) $t$. The independent variable of interest is the NEW_CEO ${ }_{i t}$ dummy, which takes the value of 1 if the (year, quarter) $i$ is a transitional quarter, and 0 otherwise. The transitional quarter is the first quarter in which the new CEO is in charge. The bank fixed effects $\beta_{i}$ enable us to control for various time-invariant factors that may be specific to the bank and that influence the bank's profitability. The fixed effects for each (year, quarter) $\beta_{t}$ allow us to control for average time trends in profitability. Many of our control variables (denoted by $X$ ) do not show crosssectional variation. For example, GDP growth varies by (year, quarter). Thus, we run the regressions after dropping time fixed effects when we include such variables.

The coefficient $\beta_{1}$ captures the impact of CEO turnover as a difference-indifference:

(3) $\begin{aligned} \beta_{1}= & \bar{Y}_{\text {transitional quarter }}-\left.\bar{Y}_{\text {other quarters }}\right|_{\text {bank experiencing CEO turnover in a (year,quarter) }} \\ & -\bar{Y}_{\text {transitional quarter }}-\left.\bar{Y}_{\text {other quarters }}\right|_{\text {banks NOT experiencing CEO turnover in (year,quarter) }} .\end{aligned}$ 


\section{Effect on LLPs}

LLPs are an easy target for discretionary earnings management in banks. For example, Bikker and Metzemakers (2004) and Kilic et al. (2012) find that bank managers use LLPs for income smoothing. All three of the hypotheses that we test (i.e., big bath, truth-telling, and personal risk management) predict that the incoming CEO is likely to increase provisions during the transitional quarter. Of course, as we discuss in Section III, the hypotheses differ in the motivation for this increase. We follow Kilic et al. (2012) in normalizing LLPs using net income before taxes and provisions.

Table 3 reports the results. In the first two columns, we use our preferred definition of the transitional quarter, which corresponds to the quarter in which the new CEO assumes charge. In the next two columns, we use our second definition of the transitional quarter, which corresponds to the first quarter in which the incoming CEO announces the bank's results. In columns 1 and 3, we report results with bank (year, quarter) and fixed effects for each (year, quarter). We find that the LLP-to-income ratio increases by $1.1 \%$ in the transitional quarter. In columns 2 and 4, we report the result of tests including additional controls, such as the bank's capital adequacy ratio, gross domestic product (GDP) growth rate, and yield on 10-year government bonds. These variables enable us to control for specific time-varying factors that may influence provisioning by all banks. Again, we find that the LLP-to-income ratio increases by approximately $1.2 \%-2.4 \%$. In all four columns, the results are statistically significant at the $95 \%$ level or higher. Because the mean LLP-to-income ratio is $13.0 \%$, our results imply an $8.5 \%$ increase in the ratio; the change is thus economically significant.

\section{TABLE 3}

Impact of CEO Turnover on LLP-to-Income Ratio

Table 3 presents ordinary least squares (OLS) regression estimates for the effect of appointment of a new bank chief executive officer (CEO) on the bank's loan loss provisions (LLPS). The dependent variable, LLP-to-income ratio, is calculated by normalizing LLPs by interest income. The key explanatory variable equals the dummy NEW_CEO, which equals 1 for the transitional quarter, and 0 otherwise. In columns 1 and 2, we use our preferred definition of the transitional quarter. Here, the transitional quarter is defined as the first quarter in which the new CEO assumes charge. In columns 3 and 4 , the first quarter for which the new CEO announces results is considered as the transitional quarter. Standard errors are clustered at the bank level, and adjusted $t$-statistics are reported in square brackets below the coefficient estimates. $\star^{*},{ }^{\star *}$, and ${ }^{* * *}$ represent statistical significance at the $10 \%, 5 \%$, and $1 \%$ levels, respectively.

\begin{tabular}{|c|c|c|c|c|}
\hline \multirow[b]{2}{*}{ Variable } & \multicolumn{4}{|c|}{ LLP-to-Income Ratio } \\
\hline & 1 & 2 & 3 & 4 \\
\hline NEW_CEO & $\begin{array}{l}0.011^{\star \star} \\
{[2.184]}\end{array}$ & $\begin{array}{l}0.012^{\star \star} \\
{[1.961]}\end{array}$ & $\begin{array}{l}0.018^{* * *} \\
{[3.602]}\end{array}$ & $\begin{array}{l}0.024^{\star \star \star} \\
{[3.459]}\end{array}$ \\
\hline Capital adequacy ratio & & $\begin{array}{c}0.003 \\
{[1.286]}\end{array}$ & & $\begin{array}{c}0.003 \\
{[1.274]}\end{array}$ \\
\hline GDP growth rate & & $\begin{array}{l}-0.000 \\
{[-0.312]}\end{array}$ & & $\begin{array}{l}-0.000 \\
{[-0.280]}\end{array}$ \\
\hline Government of India securities yield & & $\begin{array}{l}-0.018^{\star \star \star} \\
{[-5.668]}\end{array}$ & & $\begin{array}{l}-0.019^{\star \star \star} \\
{[-5.710]}\end{array}$ \\
\hline $\begin{array}{l}\text { Bank fixed effects } \\
\text { Year and quarter fixed effects }\end{array}$ & $\begin{array}{l}\text { Yes } \\
\text { Yes }\end{array}$ & $\begin{array}{l}\text { Yes } \\
\text { No }\end{array}$ & $\begin{array}{l}\text { Yes } \\
\text { Yes }\end{array}$ & $\begin{array}{l}\text { Yes } \\
\text { No }\end{array}$ \\
\hline $\begin{array}{l}\text { No. of obs. } \\
\text { No. of banks } \\
\text { Adj. } R^{2}\end{array}$ & $\begin{array}{c}882 \\
21 \\
0.436\end{array}$ & $\begin{array}{c}757 \\
21 \\
0.175\end{array}$ & $\begin{array}{c}882 \\
21 \\
0.439\end{array}$ & $\begin{array}{c}757 \\
21 \\
0.184\end{array}$ \\
\hline
\end{tabular}


FIGURE 2

Effect of New CEO on LLP-to-Income Ratio in Transition Quarter versus Other Quarters

In Figure 2, we test how the ratio of loan loss provisions (LLPs) to income varies before and after the transitional quarter. We find that in the transitional quarter, the LLP-to-income ratio is significantly higher, whereas in the other quarters, the impact is statistically insignificant. The dotted line plots the lower bound (LB) and upper bound (UB) of the 95\% confidence interval.

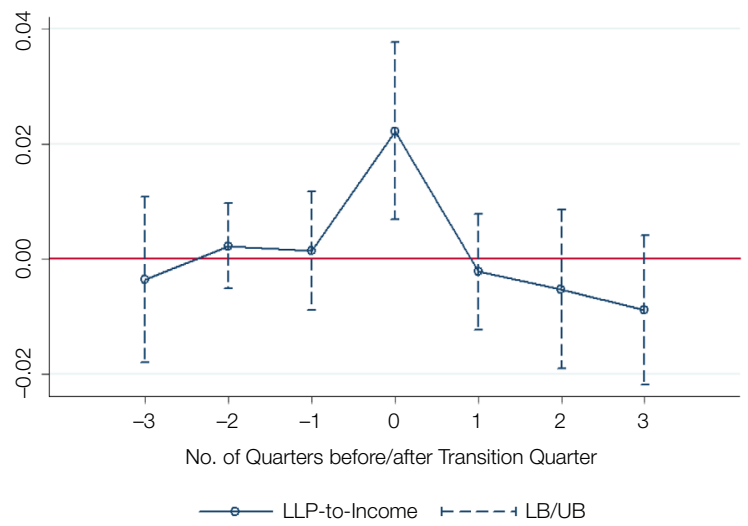

We also do an event-plot of the LLP-to-income ratio around the transitional quarter, as shown in Figure 2. We find that the ratio spikes in the transitional quarter and is statistically indistinguishable from 0 in all other quarters.

This result is consistent with all three hypotheses described in Section III. We therefore move to our second piece of evidence, the association between provisions and future NPAs, for a further examination and to distinguish between the various hypotheses.

\section{Correlation between LLPs and Future NPAs}

A question that naturally arises in this regard is whether the future increase in NPAs justifies the change in LLPs. Alternatively, does the change in LLPs reflect the anticipated change in NPAs? Bushman and Williams (2012) distinguish between the provisioning associated with earnings smoothing and that associated with timely recognition of future losses. They argue that a higher sensitivity of current LLPs to current earnings reflects earnings smoothing. They find that LLPs created to smooth earnings are associated with reduced discipline in risktaking and diminished transparency. Conversely, LLPs in anticipation of higher future losses are associated with increased discipline in risk-taking and enhanced transparency.

As in Bushman and Williams (2012), we estimate the following regression:

$$
\begin{aligned}
& \left(\mathrm{LLP}_{i, t} / \mathrm{LOAN}_{i, t-1}\right)=\beta_{0}+\beta_{i}+\beta_{t}+\beta_{1} \times \mathrm{NEW}_{-} \mathrm{CEO}_{i t} \\
& \quad+\beta_{2} \times\left(\mathrm{NPA}_{i, t+1} / \mathrm{LOAN}_{i, t}\right)+\beta_{3} \times\left(\mathrm{NPA}_{i, t} / \mathrm{LOAN}_{i, t-1}\right) \\
& \quad+\beta_{4} \times\left(\mathrm{PROFIT}_{i, t} / \mathrm{LOAN}_{i, t-1}\right) \\
& \quad+\beta_{5} \times\left(\mathrm{NPA}_{i, t+1} / \mathrm{LOAN}_{i, t}\right) \times \mathrm{NEW} \mathrm{CEO}_{i t} \\
& \quad+\beta_{6} \times\left(\mathrm{PROFIT}_{i, t} / \mathrm{LOAN}_{i, t-1}\right) \times \mathrm{NEW} \mathrm{CEO}_{i t}+\varepsilon_{i t} .
\end{aligned}
$$


Because LLPs and NPAs may comove contemporaneously, we include $\left(\mathrm{NPA}_{i, t} / \mathrm{LOAN}_{i, t-1}\right)$ to control for such comovement. Current profitability measured using (PROFIT $\left.{ }_{i, t} / \mathrm{LOAN}_{i, t-1}\right)$ captures the use of LLP for earnings smoothing. Because we are interested in the incremental correlations of LLPs with current profitability and future NPAs in the transitional quarter, the key coefficients of interest are $\beta_{5}$ and $\beta_{6}$ :

$$
\begin{aligned}
\beta_{5}= & \left.\frac{\partial\left(\mathrm{LLP}_{i, t} / \mathrm{LOAN}_{i, t-1}\right)}{\partial\left(\mathrm{NPA}_{i, t} / \mathrm{LOAN}_{i, t-1}\right)}\right|_{\text {transitional quarter }}, \\
& -\left.\frac{\partial\left(\mathrm{LLP}_{i, t} / \mathrm{LOAN}_{i, t-1}\right)}{\partial\left(\mathrm{NPA}_{i, t} / \mathrm{LOAN}_{i, t-1}\right)}\right|_{\text {other quarters }}, \\
\beta_{6}= & \left.\frac{\partial\left(\mathrm{LLP}_{i, t} / \mathrm{LOAN}_{i, t-1}\right)}{\partial\left(\mathrm{PROFIT}_{i, t} / \mathrm{LOAN}_{i, t-1}\right)}\right|_{\text {transitional quarter }} \\
& -\left.\frac{\partial\left(\mathrm{LLP}_{i, t} / \mathrm{LOAN}_{i, t-1}\right)}{\partial\left(\mathrm{PROFIT}_{i, t} / \mathrm{LOAN}_{i, t-1}\right)}\right|_{\text {other quarters }} .
\end{aligned}
$$

We report the results in Table 4. In columns 1 and 2, we examine the general relationship between LLPs, income, and NPAs. In column 1, we find a positive cor-

\begin{tabular}{|c|c|c|c|c|c|}
\hline \multirow[b]{2}{*}{ Variable } & \multicolumn{5}{|c|}{ Dependent Variable: $\operatorname{LLP}_{i, t} / \operatorname{LOAN}_{i, t-1}$} \\
\hline & 1 & 2 & 3 & 4 & 5 \\
\hline $\mathrm{NPA}_{i, t+1} / \mathrm{LOAN}_{i, t} \times \mathrm{NEW}_{-} \mathrm{CEO}_{i, t}$ & & & $\begin{array}{l}0.025^{\star \star \star} \\
{[3.322]}\end{array}$ & $\begin{array}{l}0.023^{\star * *} \\
{[2.699]}\end{array}$ & $\begin{array}{l}0.027^{\star \star \star} \\
{[2.837]}\end{array}$ \\
\hline $\begin{array}{l}\text { PROFIT_BEFORE_PROVISION } \\
\text { LOAN }_{i, t-1} / \\
\times \mathrm{NEW}_{-} \mathrm{CEO} \\
\end{array}$ & & & & $\begin{array}{l}-0.156 \\
{[-0.851]}\end{array}$ & $\begin{array}{c}-0.149 \\
{[-0.765]}\end{array}$ \\
\hline NEW_CEO & & & $\begin{array}{l}-0.035 \\
{[-0.786]}\end{array}$ & $\begin{array}{c}0.007 \\
{[0.156]}\end{array}$ & $\begin{array}{c}0.019 \\
{[0.458]}\end{array}$ \\
\hline $\begin{array}{l}\text { PROFIT_BEFORE_PROVISION } \\
\text { LOAN }_{i, t-1} /\end{array}$ & & $\begin{array}{l}0.525^{\star \star \star} \\
{[33.104]}\end{array}$ & $\begin{array}{c}0.525^{\star \star \star} \\
{[33.566]}\end{array}$ & $\begin{array}{l}0.526^{* * *} \\
{[35.021]}\end{array}$ & $\begin{array}{l}0.526^{\star \star \star} \\
{[34.449]}\end{array}$ \\
\hline $\mathrm{NPA}_{i, t} / \mathrm{LOAN}_{i, t-1}$ & $\begin{array}{l}0.483^{\star \star \star} \\
{[3.812]}\end{array}$ & $\begin{array}{l}-0.124^{\star \star \star} \\
{[-2.877]}\end{array}$ & $\begin{array}{l}-0.124^{\star \star \star} \\
{[-2.870]}\end{array}$ & $\begin{array}{l}-0.126^{\star \star *} \\
{[-2.940]}\end{array}$ & $\begin{array}{l}-0.126^{\star \star \star} \\
{[-2.875]}\end{array}$ \\
\hline $\mathrm{NPA}_{i, t+1} / \mathrm{LOAN}_{i, t}$ & $\begin{array}{c}0.006 \\
{[0.607]}\end{array}$ & $\begin{array}{l}-0.002 \\
{[-0.779]}\end{array}$ & $\begin{array}{l}-0.022^{\star \star \star} \\
{[-3.810]}\end{array}$ & $\begin{array}{l}-0.022^{\star \star *} \\
{[-3.556]}\end{array}$ & $\begin{array}{l}-0.025^{\star \star \star} \\
{[-3.194]}\end{array}$ \\
\hline Capital adequacy ratio & & & & & $\begin{array}{c}0.018 \\
{[1.042]}\end{array}$ \\
\hline GDP growth rate & & & & & $\begin{array}{l}-0.000 \\
{[-0.032]}\end{array}$ \\
\hline Government of India securities yield & & & & & $\begin{array}{l}-0.002 \\
{[-0.185]}\end{array}$ \\
\hline $\begin{array}{l}\text { Bank fixed effects } \\
\text { Year and quarter fixed effects }\end{array}$ & $\begin{array}{l}\text { Yes } \\
\text { Yes }\end{array}$ & $\begin{array}{l}\text { Yes } \\
\text { Yes }\end{array}$ & $\begin{array}{l}\text { Yes } \\
\text { Yes }\end{array}$ & $\begin{array}{l}\text { Yes } \\
\text { Yes }\end{array}$ & $\begin{array}{l}\text { Yes } \\
\text { No }\end{array}$ \\
\hline $\begin{array}{l}\text { No. of obs. } \\
\text { No. of banks } \\
\text { Adj. } R^{2}\end{array}$ & $\begin{array}{c}670 \\
21 \\
0.352\end{array}$ & $\begin{array}{c}670 \\
21 \\
0.984\end{array}$ & $\begin{array}{c}670 \\
21 \\
0.984\end{array}$ & $\begin{array}{c}670 \\
21 \\
0.984\end{array}$ & $\begin{array}{c}670 \\
21 \\
0.983\end{array}$ \\
\hline
\end{tabular}
relation between LLPs and contemporaneous levels of NPAs, with the correlation

\section{TABLE 4}

Effect of CEO Turnover on the Relationship between LLPs and Future NPAs 
between LLP and future NPAs being statistically indistinguishable from 0 . In column 2, once we control for the correlation between LLPs and contemporaneous profitability, we find that the partial correlation between LLPs and contemporaneous NPAs becomes negative. Thus, in general, although LLPs are higher when current profitability is higher, LLPs are also higher when current NPAs are lower. This seems consistent with earnings management in banks generally because the impounding of information about current delinquencies should lead to a positive correlation between LLPs and NPAs, and possibly no correlation between LLPs and current profitability. Moreover, expected NPAs captured by actual NPAs in the next period, on the other hand, are not significantly associated with LLPs. Thus, in general, LLPs do not reflect information about expected future defaults.

Having studied these correlations in general, we now focus on differences in the transitional quarters. In column 3 of Table 4, we include the interaction of the dummy with future NPAs and find that the coefficient is positive and statistically significant at the $99 \%$ level. In columns 4 and 5, we estimate the full specification in equation (4). We find that the incremental association between LLPs and next-period NPAs shown in the coefficient estimate of $\beta_{5}$ remains positive and statistically significant at the $99 \%$ level. In fact, a $1 \%$ increase in expected NPAs results in a $2.3 \%$ increase in provisions. However, the general association between LLPs and next-period NPAs is negative and significant. In effect, the correlation of 0 between LLPs and next-period NPAs shown in column 2 is a result of the overall negative association between these two variables (see columns 2-5) being offset by the positive association in the transitional quarter. Additionally, note from columns 4 and 5 that the coefficient estimate of $\beta_{6}$ is statistically indistinguishable from 0 . This suggests no significant association incrementally between LLPs and profits in the transitional quarter. In general, however, the association between LLPs and profits is positive, which indicates the general prevalence of earnings smoothing. Table 2 in the Supplementary Material reports the results of replicating the results in Table 4 using the LLP-to-income ratio as the dependent variable. Our results are qualitatively and quantitatively unchanged.

The results just presented help us rule out the big-bath hypothesis because the results indicate that i) the new CEO does not indulge in earnings management in the transitional quarter, and ii) the positive and significant association between provisions and future NPAs in the transitional quarter impounds future information about NPAs.

\section{E. Effect on Bank Profitability}

We now examine if the new CEO influences revenue items other than LLPs. To do this, we examine the impact of CEO turnover on profit before provisions and profit after provisions. If LLPs are the only revenue item affected by CEO turnover, then we do not expect any change in profit before provisions in the transitional quarter and a mechanical decline in profit after provisions driven exclusively by increased LLPs. However, if the new CEO engages in widespread earnings management, not limited only to LLPs, then it is reasonable to expect a decline in profit before provisions as well.

Table 5 presents the results of the tests. The dependent variable is profit before LLPs scaled by income in columns 1 and 2, whereas it is profit after LLPs 
TABLE 5

Impact of CEO Turnover on Profit before and after Provisions

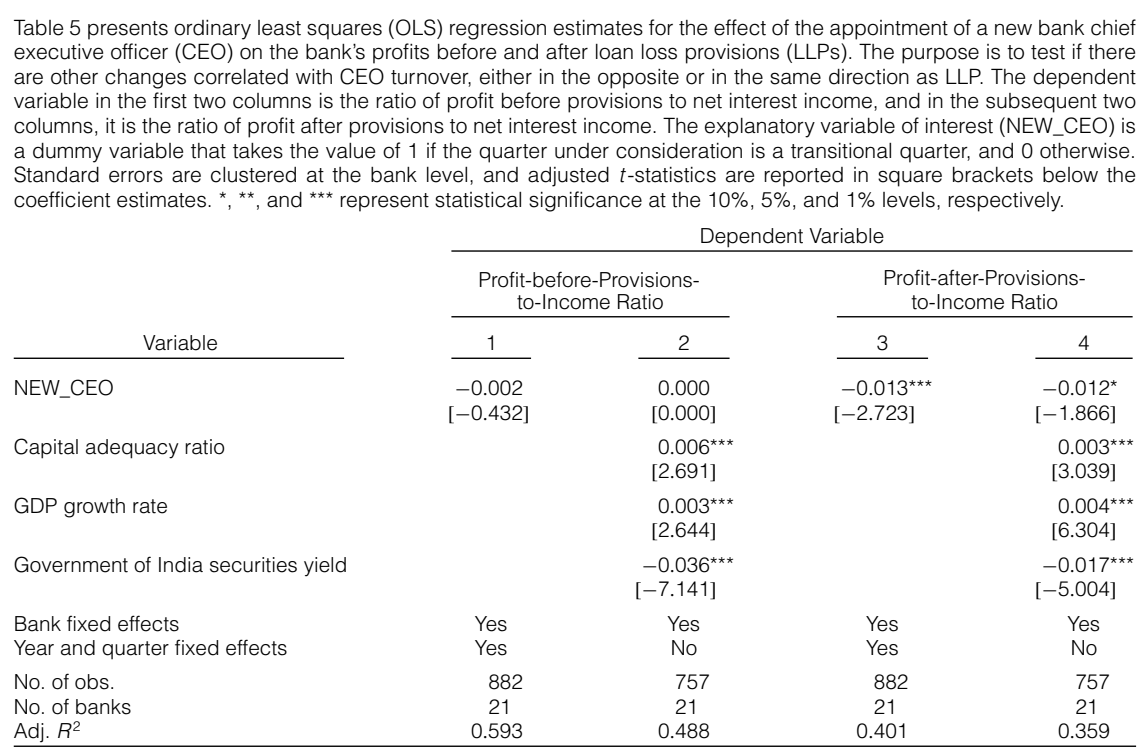

scaled by net income in columns 3 and 4 . In columns 1 and 3, we use time and bank fixed effects. In columns 2 and 4, we employ bank-level and economy-wide control variables. In columns 1 and 2, we find that profit before LLPs does not decline significantly in the transitional quarter. However, profit after LLPs declines between $1.2 \%$ and $1.3 \%$. This shows that the new CEO changes LLPs only and does not alter any other revenue item. This result is difficult to explain using the big-bath hypothesis.

As we discuss in Section III, bank managers can use LLPs not only for earnings smoothing but also to manage the bank's risk. Specifically, although high LLPs lower profitability, high LLPs increase the buffer against expected losses. Consequently, high LLPs lower the chance that a bank has to use its capital to cover unexpected losses (Laeven and Majnoni (2003)). In contrast, realized security gains and losses primarily affect earnings without affecting the buffer against expected losses. Furthermore, we found in Section VI.D that LLPs in the transitional quarter do not smooth earnings but impound information about future NPAs. Combined with this evidence, the incoming CEO increasing LLPs, but not other accounting items, suggests that the increase in LLPs relates to bank risk.

\section{F. Effect on Overall Lending}

Under the personal risk management hypothesis, CEO turnover may affect overall lending. Because banks engage in relationship lending, which involves soft, unverifiable information (Stein (2002)), incoming CEOs would fear their lack of knowledge about the quality of the loans created by their predecessors. Note that under the truth-telling and big-bath hypotheses, CEO turnover is unlikely to affect lending. 
Unlike accounting estimates such as provisions, it may not be possible for a new CEO to influence lending immediately. Therefore, we compare the total advances in the 4 quarters immediately following CEO turnover. Thus, we redefine the dummy variable NEW_CEO ${ }_{i t}$ in equation (2) to equal 1 for both the transitional quarter and the subsequent 3 quarters, and 0 otherwise. We present the results in Table 6 . In columns 1 and 2, the dependent variable is the total advances at the end of quarter $t$. In columns 3 and 4 , we winsorize the loan amount at the $1 \%$ level. In column 1 (2), we find that the total advances are lower by INR 44.0 (84.5) billion during the transitional quarters. ${ }^{10}$ Using the median advance of INR 625.8 billion, this decline represents a $7.04 \%(13.15 \%)$ fall, which is economically significant.

\section{TABLE 6}

Effect of Appointment of a New CEO on Lending

\begin{tabular}{|c|c|c|c|c|}
\hline \multirow[b]{2}{*}{ Variable } & \multicolumn{4}{|c|}{$\begin{array}{c}\text { Dependent Variable: } \\
\text { Advances (in billions of rupees) }\end{array}$} \\
\hline & 1 & 2 & 3 & 4 \\
\hline NEW_CEO & $\begin{array}{l}-44.07^{\star \star} \\
{[-2.016]}\end{array}$ & $\begin{array}{l}-84.56^{\star *} \\
{[-2.255]}\end{array}$ & $\begin{array}{l}-39.93^{\star} \\
{[-1.796]}\end{array}$ & $\begin{array}{l}-75.17^{\star \star} \\
{[-2.347]}\end{array}$ \\
\hline Capital adequacy ratio & & $\begin{array}{l}-16.14 \\
{[-0.598]}\end{array}$ & & $\begin{array}{l}-11.03 \\
{[-0.470]}\end{array}$ \\
\hline Growth in GDP & & $\begin{array}{c}-135.85^{\star \star \star} \\
{[-4.298]}\end{array}$ & & $\begin{array}{r}-125.56^{\star \star \star} \\
{[-5.518]}\end{array}$ \\
\hline Government bond yield & & $\begin{array}{c}382.10^{\star \star \star} \\
{[3.478]}\end{array}$ & & $\begin{array}{r}371.39^{\star \star \star} \\
{[3.716]}\end{array}$ \\
\hline $\begin{array}{l}\text { Bank fixed effects } \\
\text { Year and quarter fixed effects }\end{array}$ & $\begin{array}{l}\text { Yes } \\
\text { Yes }\end{array}$ & $\begin{array}{l}\text { Yes } \\
\text { No }\end{array}$ & $\begin{array}{l}\text { Yes } \\
\text { Yes }\end{array}$ & $\begin{array}{l}\text { Yes } \\
\text { No }\end{array}$ \\
\hline $\begin{array}{l}\text { No. of obs. } \\
\text { No. of banks } \\
\text { Adj. } R^{2}\end{array}$ & $\begin{array}{l}760 \\
21 \\
0.801\end{array}$ & $\begin{array}{c}732 \\
21 \\
0.724\end{array}$ & $\begin{array}{l}760 \\
21 \\
0.834\end{array}$ & $\begin{array}{l}732 \\
21 \\
0.752\end{array}$ \\
\hline
\end{tabular}

\section{G. Stock Market Impact}

The personal risk management hypothesis predicts that the incoming CEO would minimize personal risks, even if doing so is value-reducing for the bank. However, if the new CEO cuts lending to bad borrowers, stops the cycle of evergreening, and undertakes a clean-up in the spirit of truth-telling, then the stock market should react positively. Unlike the existing literature that notes negative stock returns as a reason for CEO resignation (see Weisbach (1988), Goyal and Park (2002)), CEO turnover is exogenous in our setting. Therefore, any significant stock price reaction in the transitional quarter would provide an estimate of the causal effect of CEO turnover on the stock price.

\footnotetext{
${ }^{10}$ In additional robustness tests, we re-examine these results by including calendar-month fixed effects to control for any possible seasonal effects. Our results remain unchanged.
} 
We calculate the market-adjusted return by taking the residuals from regressing the individual bank's stock return on the CNX NIFTY index, the National Stock Exchange of India's benchmark index for the Indian equity market. ${ }^{11}$ Prowess does not provide comprehensive data for quarterly results announcement dates. We thus hand-collect this data from newspapers and company Web sites and cross-check the information with Bloomberg. We use returns over the $[-165,-16]$ window to calculate the parameters of the market model and use $[-1,1]$ as the event window. To avoid incorrect estimates for relatively illiquid stocks, we require a stock to be traded for at least 120 days during the 150-day estimation window. Additionally, as we note in Section V, some banks were later in our sample period; their coverage only starts from the quarter of listing. For these tests, we therefore have a maximum of 651 observations for 20 banks. In addition, some stocks remained illiquid for some quarters after listing. We left such observations out due to our liquidity screen. Of the $21 \mathrm{GOBs}$, one bank (United Bank of India) was excluded because it consistently trades for less than 120 days during the estimation windows. However, none of our results were impacted significantly by either including or omitting this bank.

We use the cumulative abnormal returns over $[-1,1]$ as the dependent variable in equation (2). We present the results from these tests in Table 7. In columns 1 and 2, the dependent variable is the cumulative return and the cumulative abnormal return, respectively, on bank stock $i$ during the event window. We include bank- and quarter-level fixed effects in all four specifications.

TABLE 7

Market Reaction to Results Announced by a New CEO

Table 7 reports ordinary least squares (OLS) regression estimates for the bank stock price reaction to results announced by the new chief executive officer (CEO). The dependent variable in column 1 is the cumulative stock returns during the 3-day interval around the bank results announcement. In column 2, we use cumulative abnormal returns (CARs) calculated using the capital asset pricing model (CAPM). We use all of the data provided by Prowess. We include bank and quarter fixed effects. Standard errors are clustered at the bank level, and adjusted $t$-statistics are reported in square brackets below the coefficient estimates. ${ }^{*},{ }^{* *}$, and ${ }^{* * *}$ represent statistical significance at the $10 \%, 5 \%$, and $1 \%$ levels, respectively.

\begin{tabular}{lcc} 
& \multicolumn{2}{c}{ Dependent Variable } \\
\cline { 2 - 3 } \multicolumn{1}{c}{ Variable } & $\begin{array}{c}\text { Cumulative } \\
\text { Stock } \\
\text { Returns }\end{array}$ & CARs \\
\cline { 2 - 3 } NEW_CEO & 1 & 2 \\
\cline { 2 - 3 } Bank fixed effects & $-0.015^{\star}$ & $-0.017^{\star \star}$ \\
Year and quarter fixed effects & {$[-1.681]$} & {$[-2.421]$} \\
No. of obs. & Yes & Yes \\
No. of banks & Yes & Yes \\
Adj. $R^{2}$ & 651 & 651 \\
\hline
\end{tabular}

The results clearly show that the market reacts negatively to results announced by a new CEO. The cumulative abnormal return (cumulative return) is lower, by $1.7 \%(1.5 \%)$, during transitional quarters compared with other quarters. This clearly shows that new CEOs' risk aversion has real negative effects on

\footnotetext{
${ }^{11}$ By trading volume, the National Stock Exchange is the largest stock exchange in India.
} 
shareholder wealth. Further, these results help us to alleviate concerns that our results are driven by the new CEO terminating ever-greening, connected lending, and/or politically motivated lending. If these alternative explanations were correct, the stock prices should have reacted positively.

\section{H. Asymmetric Information}

We argue that CEO turnover affects bank policies due to the significant information asymmetry that new bank CEOs face. To provide evidence of this mechanism, we conduct two sets of placebo tests. First, as in Table 2, none of the key financial variables changes significantly before the transitional quarter. This suggests that changes in bank policies occur under the new CEO and not the outgoing $\mathrm{CEO}$, which is consistent with the hypothesis that incoming CEOs face information asymmetry, whereas the outgoing ones do not.

Second, we investigate whether any changes in firm policies occur that coincide with CEO turnover in similar government-owned nonfinancial firms. As we mention in Section III, problems due to information asymmetry are lower in nonfinancial firms than in banks. If our results are indeed driven by information asymmetry, then we do not expect them to manifest in this sample of governmentowned nonfinancial firms. If, however, our results are driven government ownership, then we are likely to find abnormal behavior in the key variable around CEO turnover, even in this sample. Table 8 reports the results, which show that profit does not decline significantly for nonbank government-owned companies. Similarly, we see no change in standardized unexpected earnings. Because these are nonfinancial firms, we cannot examine their lending. This evidence indicating no changes in government-owned nonfinancial firms suggests that our main results stem from the issue of information asymmetry that characterizes banks. Moreover, this evidence demonstrates that our main results do not stem from any peculiarities associated with government ownership of banks.

TABLE 8

Impact of New CEO's Appointment on Firm Performance for Nonbank PSUs

Table 8 presents ordinary least squares (OLS) regression estimates for the effect of appointment of a new CEO on various profit-to-income ratios and standardized unexpected earnings (SUEs) for nonbank public-sector units (PSUs). In column 1 , the dependent variable is the profit-to-income ratio, and in column 2 the dependent variable is SUE. The key explanatory variable equals the dummy NEW_CEO, which equals 1 for the transitional quarter, and 0 otherwise. Standard errors are clustered at the bank level, and adjusted $t$-statistics are reported in square brackets below the coefficient estimates. *, $* \star$, and ${ }^{* \star *}$ represent statistical significance at the $10 \%, 5 \%$, and $1 \%$ levels, respectively.

\begin{tabular}{|c|c|c|}
\hline & \multicolumn{2}{|c|}{ Dependent Variable } \\
\hline & $\begin{array}{c}\text { Profit-to-Sales } \\
\text { Ratio }\end{array}$ & SUE \\
\hline Variable & 1 & 2 \\
\hline NEW_CEO & $\begin{array}{l}-0.027 \\
(-1.421)\end{array}$ & $\begin{array}{l}-0.207 \\
(-1.399)\end{array}$ \\
\hline GDP growth & $\begin{array}{c}0.001 \\
(0.333)\end{array}$ & $\begin{array}{c}0.025 \\
(1.191)\end{array}$ \\
\hline Government of India securities yield & $\begin{array}{l}0.003 \\
(0.200)\end{array}$ & $\begin{array}{l}-0.013 \\
(-0.255)\end{array}$ \\
\hline $\begin{array}{l}\text { Company fixed effects } \\
\text { Year and quarter fixed effects }\end{array}$ & $\begin{array}{l}\text { Yes } \\
\text { Yes }\end{array}$ & $\begin{array}{l}\text { Yes } \\
\text { Yes }\end{array}$ \\
\hline $\begin{array}{l}\text { Adj. } R^{2} \\
\text { No. of obs. }\end{array}$ & $\begin{array}{l}0.013 \\
1,093\end{array}$ & $\begin{array}{l}0.002 \\
1,093\end{array}$ \\
\hline
\end{tabular}




\section{Motivation for Incoming CEOs' Actions}

To provide further evidence of personal risk management, we now examine if postretirement career concerns motivate such risk management. Brickley, Linck, and Coles (1999) argue that (inside and outside) board memberships after retirement provide powerful incentives for CEOs. Gupta (2005) shows that CEOs of Indian government-owned firms that exhibit better performance receive more board offers after retirement. Accordingly, we test if greater performance management by a bank CEO in our sample correlates with board appointments in other firms after retirement. Because we are interested in the "managed" component of performance, we measure the growth rate in profits from the first quarter in which a CEO is in charge to the last quarter he or she is in charge. We compare this measure vis-à-vis the benchmark provided by actual performance measured by the growth rate in profits from the last quarter the previous CEO was in charge to the last quarter the current CEO was in charge. Because our sample ends in the Apr.-June quarter of 2013, in the case of CEOs exiting at the end of the sample, we can only observe the board appointments secured within 2 years of retirement. To avoid this right-censoring bias, we uniformly restrict board memberships to those received within 2 years of retirement. Because the sample for these tests consists of the 64 CEOs who retired during our sample period, the sample is not adequate for multivariate tests. Therefore, we restrict the analysis to a simple $t$-test for the difference in the means between the sample of CEOs who were given a board membership and those who were not. We report the results in Table 9. For the group that received a board membership within 2 years after retirement, we find that the "managed" component of performance is approximately $8 \%$ higher than for the group that does not receive a board membership during the same period. This result shows that incoming CEOs' performance management in the transitional quarter is associated with more directorships postretirement. Note that CEOs who receive a board membership may be more ambitious or more qualified. Since our tests only test for the association between performance management by the incoming CEO and subsequent board memberships, we cannot rule out such self-selection. Therefore, this evidence only suggests that postretirement career concerns influence personal risk management by the incoming CEO.

TABLE 9

Possible Motivation for Incoming CEO's Actions: Board Positions Postretirement

Table 9 reports the result from a simple $t$-test to analyze the difference in the degree of manipulation between two groups: Group 0 , with the chairperson getting at least one directorship in other companies within 2 years postretirement, and Group 1, with the chairperson getting no directorship in other companies within 2 years postretirement. ${ }^{*},{ }^{* *}$, and ${ }^{* \star *}$ represent statistical significance at the $10 \%, 5 \%$, and $1 \%$ levels, respectively.

Degree of Manipulation

No directorship (Group 0) At least 1 directorship (Group 1)

Difference (Group 0-Group 1)

\begin{tabular}{ccc} 
No. of Obs. & \multicolumn{1}{c}{ Mean } & $\frac{\text { Std. Error }}{43}$ \\
\cline { 3 - 3 } 16 & 0.0016 & 0.019 \\
& 0.085 & 0.051 \\
& $-0.0841^{*}$ & 0.020 \\
\hline
\end{tabular}




\section{Alternative Explanations and Data Concerns}

Our study focuses on Indian GOBs to overcome the identification challenges of the endogeneity of CEO turnover. However, concerns about data quality and peculiarities related to GOBs naturally arise. As we argue in the Introduction, including bank and year fixed effects and using other GOBs that do not experience CEO turnover as a control group significantly alleviates such concerns.

For instance, consider politically connected lending. Bank fixed effects should control for time-invariant, bank-specific differences in politically connected lending. Similarly, we control for the common factors that affect politically connected lending across all banks in a (quarter, year) by the fixed effects for each (quarter, year) pair. Finally, GOBs in India are very similar to each other. For instance, the deputy governor of the Reserve Bank of India argues that India "has too many GOBs with very similar characteristics." Since politically connected lending affects all GOBs similarly, using GOBs that do not experience CEO turnover in a particular (quarter, year) as a control group enables us to account for various time-varying factors as well. In fact, any factor that does not vary systematically between the transitional quarter and other quarters cannot affect our results. Nonetheless, we examine such concerns directly.

\section{A. Politically Motivated Lending?}

First, we investigate if our results stem from outgoing CEOs' lending to politically connected firms. In this case, it is possible that the incoming CEO's higher provisioning and reduction in lending may be intended to correct this malaise. A number of studies show that GOBs are indeed subject to political interference (Dinç (2005), Khwaja and Mian (2005), Sapienza (2004), and Cole (2008)).

Politically appointed CEOs would owe their allegiance to the government of the day. Thus, we use the unexpected change in the federal government from the incumbent National Democratic Alliance (NDA) to the United Progressive Alliance (UPA) in 2004 to examine if politically connected lending impacts our results. For this purpose, we focus on outgoing-incoming CEO pairs where both CEOs were appointed by the same government. In such pairs, both CEOs are likely to owe their allegiance to the same set of political masters. If the outgoing CEO in this group lends to politically connected firms, the incoming CEO in this group is unlikely to upset the status quo. Note that there is no reason to believe that the incoming CEO will be systematically less prone to political influence than the outgoing CEO because every new CEO becomes an old CEO when handing the charge of a bank to the successor. Thus, for these pairs of CEOs, it is unlikely that the political influence on CEOs will differ significantly between transitional and other quarters. In other words, in this group of CEOs, the incoming CEO is unlikely to reduce lending. If our results stem from outgoing CEOs' lending to politically connected firms, then the difference between the transitional quarter and other quarters should not manifest for these CEO pairs. 
To test this thesis, we repeat the specifications in Tables 3 and 6 for the subsample of cases where the same government appointed both the outgoing and incoming CEOs. We report the results in Table 10. In line with our earlier results, LLPs increase significantly in the transitional quarter, and lending declines significantly. Thus, we can infer that our results are unlikely to stem from lending to politically connected firms.

TABLE 10

Impact of CEO Turnover on LLP-to-Income and Lending-CEO Pair Appointed by the Same Political Party

Table 10 presents ordinary least squares (OLS) regression estimates for the effect of appointment of a new bank chief executive officer (CEO) on the bank's loan loss provisions (LLPS) and lending. Panel A presents the results for the impact on the LLP-to-income ratio. Panel B presents the results for the impact on lending. The sample is restricted to outgoingincoming CEO pairs that are appointed by the same government at the federal level. The dependent variable in Panel A, LLP-to-income ratio, is calculated by normalizing LLPs by interest income. The key explanatory variable equals the dummy NEW_CEO, which equals 1 for the transitional quarter, and 0 otherwise. In columns 1 and 2 of Panel A, we use our preferred definition of the transitional quarter. Here, the transitional quarter is defined as the first quarter in which the new CEO assumes charge. In columns 3 and 4 in Panel $A$, the first quarter for which the new CEO announces results is considered as the transitional quarter. In columns 1 and 2 of Panel B, the dependent variable is the total advances (in billions of rupees) lent. The data pertaining to bank-borrower pair span from 2001 to 2014 . The independent variable (NEW CEO) takes the value of 1 for the transitional quarter and the 3 successive quarters following the turnover quarter, and 0 otherwise. Standard errors are clustered at the bank level, and adjusted $t$-statistics are reported in square brackets below the coefficient estimates. ${ }^{*}{ }^{* *}$, and ${ }^{* \star}$ represent statistical significance at the $10 \%, 5 \%$, and $1 \%$ levels, respectively.

Panel A. Impact on Loan Loss Provision

\begin{tabular}{|c|c|c|c|c|}
\hline \multirow[b]{2}{*}{ Variable } & \multicolumn{4}{|c|}{ Dependent Variable: LLP-to-Income-Ratio } \\
\hline & 1 & 2 & 3 & 4 \\
\hline NEW_CEO & $\begin{array}{l}0.016^{\star \star \star} \\
{[3.481]}\end{array}$ & $\begin{array}{l}0.011^{\star \star} \\
{[1.988]}\end{array}$ & $\begin{array}{l}0.019^{* * *} \\
{[3.031]}\end{array}$ & $\begin{array}{r}0.010^{\star} \\
{[1.736]}\end{array}$ \\
\hline Capital adequacy ratio & & $\begin{array}{c}0.005 \\
{[1.156]}\end{array}$ & & $\begin{array}{l}0.006 \\
{[1.154]}\end{array}$ \\
\hline GDP growth rate & & $\begin{array}{l}-0.000 \\
{[-0.282]}\end{array}$ & & $\begin{array}{l}-0.000 \\
{[-0.247]}\end{array}$ \\
\hline Government of India securities yield & & $\begin{array}{l}-0.014^{\star \star \star} \\
{[-5.117]}\end{array}$ & & $\begin{array}{l}-0.016^{\star \star \star} \\
{[-5.723]}\end{array}$ \\
\hline No. of banks & 21 & 21 & 21 & 21 \\
\hline $\begin{array}{l}\text { Firm fixed effects } \\
\text { Year and quarter fixed effects }\end{array}$ & $\begin{array}{l}\text { Yes } \\
\text { Yes }\end{array}$ & $\begin{array}{l}\text { Yes } \\
\text { Yes }\end{array}$ & $\begin{array}{l}\text { Yes } \\
\text { Yes }\end{array}$ & $\begin{array}{l}\text { Yes } \\
\text { Yes }\end{array}$ \\
\hline $\begin{array}{l}\text { No. of obs. } \\
\text { Adj. } R^{2}\end{array}$ & $\begin{array}{r}682 \\
0.627\end{array}$ & $\begin{array}{r}682 \\
0.627\end{array}$ & $\begin{array}{r}554 \\
0.285\end{array}$ & $\begin{array}{r}554 \\
0.285\end{array}$ \\
\hline \multicolumn{5}{|l|}{ Panel B. Impact on Advances } \\
\hline & & \multicolumn{3}{|c|}{$\begin{array}{l}\text { Dependent Variable: } \\
\text { Advances (in billions of rupees) }\end{array}$} \\
\hline Variable & & 1 & & 2 \\
\hline NEW_CEO & & $\begin{array}{r}-102.45^{\star *} \\
{[-2.363]}\end{array}$ & & $\begin{array}{c}-107.79^{\star \star *} \\
{[-2.730]}\end{array}$ \\
\hline Capital adequacy ratio & & $\begin{array}{c}0.571 \\
{[0.026]}\end{array}$ & & $\begin{array}{l}-1.58 \\
{[-0.075]}\end{array}$ \\
\hline GDP growth rate & & $\begin{array}{c}-108.67^{\star * *} \\
{[-7.151]}\end{array}$ & & $\begin{array}{c}-108.14^{* * *} \\
{[-7.203]}\end{array}$ \\
\hline Government of India securities yield & & $\begin{array}{c}178.39^{\star \star \star} \\
{[7.024]}\end{array}$ & & $\begin{array}{c}178.93^{\star \star \star} \\
{[7.153]}\end{array}$ \\
\hline No. of obs. & & 532 & & 532 \\
\hline $\begin{array}{l}\text { Firm fixed effects } \\
\text { Year and quarter fixed effects }\end{array}$ & & $\begin{array}{l}\text { Yes } \\
\text { Yes }\end{array}$ & & $\begin{array}{l}\text { Yes } \\
\text { No }\end{array}$ \\
\hline $\begin{array}{l}\text { No. of banks } \\
\text { Adj. } R^{2}\end{array}$ & & $\begin{array}{c}21 \\
0.777\end{array}$ & & $\begin{array}{c}21 \\
0.777\end{array}$ \\
\hline
\end{tabular}




\section{B. Ever-Greening of Loans?}

Next, we examine if our results stem from possible ever-greening by the outgoing CEO. To identify ever-greening, we use the findings from the literature on ever-greening and zombie lending (Peek and Rosengren (2005), Bruche and Llobet (2014), Caballero et al. (2008), Hoshi and Kashyap (2004), and Rogoff (2002)). We then examine if the incoming CEO reduces lending to such categories of borrowers.

\section{Pre-Existing Relationships}

Peek and Rosengren (2005) show that one of the prerequisites for zombie lending is a pre-existing relationship. It is unlikely that outgoing CEOs evergreen the loans of borrowers with whom they do not have an existing relationship. Note that any revelation or admission of guilt by the borrower that a loan was ever-greened could land the $\mathrm{CEO}$ in trouble because federal anti-corruption agencies can investigate bank CEOs even after retirement (Banerjee, Cole, and Duflo (2008)). Therefore, for ever-greening to manifest, it is necessary that the borrower and the outgoing CEO trust each other. Such trust is more likely in cases where a prior banking relationship exists between the borrower and the bank under the outgoing CEO's leadership.

We use data at the firm-quarter level on bank-borrower relationships provided by CMIE Prowess. Using these data, we estimate the following regression:

$$
\begin{aligned}
& \text { NOT_RENEWED }{ }_{i j t}=\alpha+v_{i}+\delta_{j}+\theta_{t} \\
& \quad+\beta_{1} \times \text { NEW_CEO } j t \times \text { RELATIONSHIP_BORROWER } i \\
& \quad+\beta_{2} \times \text { NEW_CEO } i t \\
& +\epsilon_{i j t},
\end{aligned}
$$

where NOT_RENEWED ${ }_{i j t}$ is a dummy variable that takes the value of 1 if firm $i$ 's relationship with bank $j$ is not renewed in year $t$, and 0 otherwise; RELATIONSHIP_BORROWER $_{i}$ is a borrower that had at least a 3-year continuous relationship with the bank; and NEW_CEO ${ }_{j t}$ is defined as before. We include bank, firm, and year fixed effects. We focus on the interaction be-

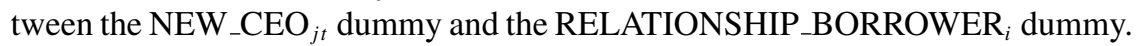
This term captures whether a relationship borrower has a higher chance of being dropped in the transitional quarter compared with a nonrelationship borrower.

We present the results in column 1 of Table 11, which shows that the coefficient estimate for $\beta_{1}$ is statistically insignificant. Therefore, it is clear that the new CEO does not show any greater tendency to not renew loans to relationship borrowers. 
TABLE 11

Termination of Ever-Greening following CEO Turnover

Table 11 reports ordinary least squares (OLS) estimates of estimates for the effect of appointment of a new chief executive officer (CEO) on possible ever-greening. The data are organized at the borrower-bank-year level. The dependent variable, LOANS_NOT_RENEWED, takes the value of 1 if the loan to borrower $i$ is not renewed by bank $j$ in year $t$, and 0 otherwise. LOSS is a dummy variable that takes the value of 1 for firms that reported negative profits for the immediately preceding year, and 0 otherwise. RELATIONSHIP_BORROWER is a dummy variable that takes the value of 1 for firms that have a 3-year continuous relationship with the bank, and 0 otherwise. LARGE is a dummy variable that takes the value of 1 for firms whose value of total assets is above the average for any year, and 0 otherwise. PRIORITY is a dummy variable that takes the value of 1 for a firm that is eligible for priority-sector loans, and 0 otherwise. Standard errors are clustered at the bank level, and adjusted $t$-statistics are reported in square brackets below the coefficient estimates. * ${ }^{* *}$, and ${ }^{* * *}$ represent statistical significance at the $10 \%, 5 \%$, and $1 \%$ levels, respectively.

\begin{tabular}{|c|c|c|c|c|}
\hline \multirow[b]{2}{*}{ Variable } & \multicolumn{4}{|c|}{ Dependent Variable: LOANS_NOT_RENEWED } \\
\hline & 1 & 2 & 3 & 4 \\
\hline NEW_CEO $\times$ RELATIONSHIP_BORROWER & $\begin{array}{l}-0.006 \\
{[-0.685]}\end{array}$ & & & \\
\hline NEW_CEO $\times$ LOSS & & $\begin{array}{c}0.007 \\
{[1.350]}\end{array}$ & & \\
\hline NEW_CEO $\times$ LARGE & & & $\begin{array}{r}-0.012^{\star} \\
{[-1.823]}\end{array}$ & \\
\hline NEW_CEO $\times$ PRIORITY & & & & $\begin{array}{c}0.002 \\
{[0.312]}\end{array}$ \\
\hline LOSS & $\begin{array}{l}0.018^{* *} \\
{[2.521]}\end{array}$ & & & \\
\hline RELATIONSHIP_BORROWER & & $\begin{array}{c}0.009 \\
{[1.110]}\end{array}$ & & \\
\hline LARGE & & & $\begin{array}{l}-0.077^{\star * *} \\
{[-5.180]}\end{array}$ & \\
\hline PRIORITY & & & & $\begin{array}{l}-0.011^{* * *} \\
{[-2.764]}\end{array}$ \\
\hline NEW_CEO & $\begin{array}{l}-0.009^{\star *} \\
{[-1.981]}\end{array}$ & $\begin{array}{l}-0.001 \\
{[-0.167]}\end{array}$ & $\begin{array}{l}-0.002 \\
{[-0.958]}\end{array}$ & $\begin{array}{c}-0.004 \\
{[-1.439]}\end{array}$ \\
\hline $\begin{array}{l}\text { Bank fixed effects } \\
\text { Borrower fixed effects } \\
\text { Year and quarter fixed effects }\end{array}$ & $\begin{array}{l}\text { Yes } \\
\text { Yes } \\
\text { Yes }\end{array}$ & $\begin{array}{l}\text { Yes } \\
\text { Yes } \\
\text { Yes }\end{array}$ & $\begin{array}{l}\text { Yes } \\
\text { Yes } \\
\text { Yes }\end{array}$ & $\begin{array}{l}\text { Yes } \\
\text { Yes } \\
\text { Yes }\end{array}$ \\
\hline $\begin{array}{l}\text { No. of obs. } \\
\text { Adj. } R^{2}\end{array}$ & $\begin{array}{r}44,316 \\
0.857 \\
\end{array}$ & $\begin{array}{r}44,316 \\
0.857 \\
\end{array}$ & $\begin{array}{r}44,316 \\
0.864 \\
\end{array}$ & $\begin{array}{r}44,316 \\
0.014 \\
\end{array}$ \\
\hline
\end{tabular}

\section{Loss-Making Firms}

Loans made to loss-making firms are more likely to be ever-greened compared with loans made to healthy firms (Peek and Rosengren (2005)). Based on this argument, we examine if the incoming CEO is more likely to not renew loans to loss-making firms. We identify firms whose net profit in the immediately preceding year was negative. We estimate regression equation (7)

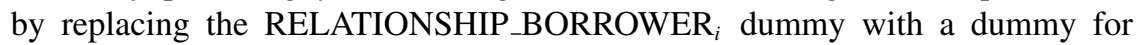
loss-making firms. We report the result in column 2 of Table 11. As in column 1 , the coefficient estimate for $\beta_{1}$ is statistically insignificant. Therefore, it is unlikely that new CEOs show a higher tendency to not renew loans to loss-making firms.

\section{Large Firms}

Ever-greening occurs to window-dress loan accounts, that is, to show fewer defaults than the actual levels (Peek and Rosengren (2005)). There is a cost associated with the possibility of being caught and punished. So, maintaining secrecy is critical for successful ever-greening. The outgoing CEO may find it safer to 
ever-green some large loans rather than ever-green a large number of small loans. As well, large firms may offer postretirement career opportunities to the outgoing CEO as a quid pro quo (Brickley et al. (1999)). Therefore, if a new CEO stops ever-greening, large firms are less likely to be renewed.

To test this thesis, we estimate regression equation (7) by replacing the RELATIONSHIP_BORROWER dummy with a dummy for large firms, defined as those with assets greater than the median. We classify assets for every year. We report the results in column 3 of Table 11 . Here again, we find a statistically significant coefficient estimate of $\beta_{1}$ only at the $10 \%$ level. The results suggest very little difference in renewals of loans by new CEOs to large firms.

\section{Priority-Sector Lending}

All banks in India, including private-sector banks, are mandated by law to direct at least $40 \%$ of their total credit to "priority-sector loans." Priority sectors include, inter alia, agriculture, small and medium enterprises, small ticket housing loans, and education loans. Given this lending mandate, it is quite possible that CEOs engage in ever-greening to reach priority-sector targets (Tzioumis and Gee (2013)).

Among the borrowers covered by the data provided in CMIE Prowess, we identify firms eligible for priority-sector loans. Firms whose investment in plant and machinery does not cross INR 10 million are considered small and medium enterprises (Banerjee and Duflo (2014)). This definition was revised to INR 50 million in Oct. 2006. Using these definitions, we estimate regression equation

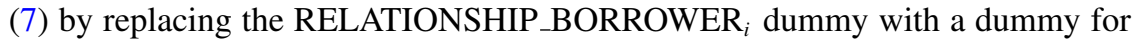
firms eligible for priority-sector loans. If the outgoing CEO ever-greens loans to reach priority-sector lending targets and the new CEO does not renew such evergreened loans, then loans to firms eligible for priority-sector lending are less likely to be renewed in the transitional quarter.

We present the results of these tests in column 4 of Table 11. The interaction between new CEO and the SME dummy is statistically indistinguishable from 0 . Therefore, based on this result, it is reasonable to conclude that our results are not driven by ever-greening with the purpose of fulfilling priority-sector requirements.

Overall, we therefore conclude that our results are unlikely to stem from ever-greening by the outgoing $\mathrm{CEO}$ and the incoming $\mathrm{CEO}$ rectifying this phenomenon.

\section{Quality of GOBs' Data}

Given our empirical setting, readers may have concerns about the quality of data provided by GOBs. In this section, we describe the extensive list of institutional reasons and supporting empirical evidence to mitigate this concern. We describe the institutional reasons before describing our formal empirical tests.

\section{Institutional Factors}

Several institutional reasons mitigate concerns about the quality of GOBs' data.

First, all Indian GOBs are partially privatized. Nongovernment ownership ranges between $25 \%$ and $45 \%$. All GOBs are corporations under the law and are subject to the Banking Regulation Act of 1949 and the Reserve Bank of India 
(RBI) Act of 1934. GOBs are subject to the same corporate governance and audit requirements as are private-sector banks. De jure, the GOBs that we study are not run as departmental undertakings but as commercial enterprises subject to the same rules and regulations as private-sector banks.

Second, although GOBs are subject to political intervention (Dinç (2005), Cole (2009)), oversight by the independent central bank (RBI) provides a strong counterbalancing force. India's central bank has a reputation as an independent and competent central bank (Bardhan (1999), Bhagwati (1993)).

Third, every board and its audit committee in a GOB includes a representative from the RBI as its member. The RBI appoints very senior officials, including deputy governors and executive directors, as RBI representatives on bank boards and their audit committees.

Fourth, the RBI requires banks to produce various granular reports frequently; the numbers reported in these reports are cross-validated with those reported in financial statements. Some of these reports cover connected lending, asset liability management, large credits, capital adequacy, and so on.

\section{Tests for the Quality of GOBs' Data}

As we argued earlier, institutional factors alleviate concerns about the quality of GOBs' data. Nevertheless, by conducting additional tests, we dispel residual concerns about the quality of data reported by GOBs. For brevity, we describe these results here and present a detailed description in the Supplementary Material.

First, dispersion in analysts' forecasts is a good proxy for a company's level of accounting transparency (Barron and Stuerke (1998), Avramov, Chordia, Jostova, and Philipov (2009), Zhang (2006), and Morgan (2002)). Accordingly, we test and find that the dispersion in analyst's earnings forecasts is similar for private-sector banks and GOBs. Because private-sector banks are similar to the banks in the United States, the United Kingdom, and other countries, they serve as a useful benchmark for comparison. Furthermore, within GOBs, we find no significant difference in such dispersion between the transitional quarter and other quarters.

Second, the accounting literature documents that if a company's earnings are credible, then markets should react in the direction of the earnings announced (Healy and Wahlen (1999), Dechow, Ge, and Schrand (2010), Ecker, Francis, Kim, Olsson, and Schipper (2006), Teoh and Wong (1993), Barron, Kile, and O'Keefe (1999), and Imhoff and Lobo (1992)). Thus, we compare the association between earnings surprises in GOBs and the stock market reaction. Here again, we find results consistent with credible earnings estimates from GOBs.

Third, to examine the sanctity of the data on lending, we use monetary-policy shocks and examine the response of GOBs and private-sector banks. Any discrepancy in the quality of lending data for GOBs should manifest as differences in the response magnitudes for GOBs and private-sector banks. However, we find no difference in the response to the monetary-policy shock between GOBs and private-sector banks. Recall that the private-sector banks are similar to banks in the United States, the United Kingdom, and other countries and therefore serve as a useful benchmark for comparison. Moreover, we find no difference in the 
response of lending to monetary policy shocks between the transitional quarter and other quarters. These tests assure us about the quality of GOBs' lending data.

Finally, we examine our results for a subsample of GOBs with high foreign institutional ownership. The governance and reporting standards in such GOBs are likely to be higher than those in other GOBs (Aggarwal, Erel, Ferreira, and Matos (2011)). If our results were due to poor data quality, we should find differences based on governance and reporting standards in GOBs. However, our results using this subsample remain similar to those for the full sample, which also alleviates concerns about data quality.

In sum, we conclude that our results do not stem from poor-quality data for GOBs.

\section{Missing Data}

As we note in Section $\mathrm{V}$, the primary reason for missing data is that data are available for a GOB only after it is listed in the stock market. To show that missing data do not account for our results, we create a subsample of banks with no missing data. We start from the end of the sample and stop when we encounter the first missing observation for any variable used in the regression.

We present the results using this sample in Table 12. In columns 1 and 2, we find that our earlier results (decline in LLPs and loans in transitional quarters) continue to hold with similar economic magnitudes. In columns 3 and 4, we use data on stock price reactions for the last 10 quarters for 20 banks for which no

\section{TABLE 12}

\section{Effect of Appointment of a New CEO: Tests Using Sample with No Missing Data}

Table 12 reports ordinary least squares (OLS) regression estimates for the effect of appointment of a new chief executive officer (CEO) on provisions, lending, and stock value for a subsample that does not have any missing data. The sample is selected by working backward from the last quarter. In columns 1 and 2 the dependent variables are the ratio between loan loss provisions (LLPS) and SALES and the total advances (in billions of rupees) lent. The dependent variable in column 3 is the cumulative stock returns during the 3 -day interval around the bank results announcement. In column 2, we use cumulative abnormal returns (CARs) calculated using the capital asset pricing model (CAPM) as the dependent variable. The definition of NEW_CEO is the same as in Table 2. The independent variable (NEW_CEO) takes the value of 1 for the CEO transitional quarter and the three successive quarters following the turnover quarter, and 0 otherwise. We include bank and quarter fixed effects. Standard errors are clustered at the bank level, and adjusted $t$-statistics are reported in square brackets below the coefficient estimates. ${ }^{*},{ }^{* *}$, and ${ }^{* \star *}$ represent statistical significance at the $10 \%$, $5 \%$, and $1 \%$ levels, respectively.

\begin{tabular}{llll}
\multicolumn{4}{c}{ Sample Period } \\
\hline 2008:Q4- & 2006:Q3- & 2010:Q3- & 2010:Q3- \\
2012:Q4 & 2012:Q4 & 2012:Q4 & 2012:Q4 \\
& \multicolumn{2}{c}{ Dependent Variable } & \\
\hline
\end{tabular}

\begin{tabular}{|c|c|c|c|c|}
\hline & LLP-to-Income & $\begin{array}{c}\text { Advances } \\
\text { (in billions of rupees) }\end{array}$ & $\begin{array}{c}\text { Cumulative } \\
\text { Stock } \\
\text { Returns }\end{array}$ & CARs \\
\hline Variable & 1 & 2 & 3 & 4 \\
\hline NEW_CEO & $\begin{array}{l}0.016^{* * *} \\
{[2.640]}\end{array}$ & $\begin{array}{l}-69.69^{*} \\
{[-1.707]}\end{array}$ & $\begin{array}{l}-0.031^{\star \star} \\
{[-2.181]}\end{array}$ & $\begin{array}{l}-0.025^{\star \star} \\
{[-2.221]}\end{array}$ \\
\hline No. of obs. & 340 & 390 & 194 & 194 \\
\hline $\begin{array}{l}\text { Bank fixed effects } \\
\text { Year and quarter fixed effects }\end{array}$ & $\begin{array}{l}\text { Yes } \\
\text { Yes }\end{array}$ & $\begin{array}{l}\text { Yes } \\
\text { Yes }\end{array}$ & $\begin{array}{l}\text { Yes } \\
\text { Yes }\end{array}$ & $\begin{array}{l}\text { Yes } \\
\text { Yes }\end{array}$ \\
\hline $\begin{array}{l}\text { No. of banks } \\
\text { Adj. } R^{2}\end{array}$ & $\begin{array}{c}20 \\
0.400\end{array}$ & $\begin{array}{c}15 \\
0.900\end{array}$ & $\begin{array}{c}20 \\
0.329\end{array}$ & $\begin{array}{c}20 \\
0.275\end{array}$ \\
\hline
\end{tabular}


data are missing. Although we have information about all 200 observations, we dropped 6 observations due to our liquidity screen. Hence, we have 194 observations in these tests. In these columns, we find that the cumulative return and the cumulative abnormal return on bank stock $i$ during the event window declines by $3.1 \%$ and $2.5 \%$, respectively. Based on these findings, it is reasonable to infer that missing data do not impact our results systematically.

\section{Conclusion}

We examine the effects of CEO turnover on banks' policies. To overcome the identification challenges posed by endogenous CEO turnover, we exploit exogenous variation generated by age-based CEO retirement policies in Indian GOBs. We find that incoming CEOs change bank policies to manage their personal risks by i) increasing provisioning for future delinquencies and ii) shrinking lending. Politically motivated lending, ever-greening, or the quality of data in GOBs cannot explain these findings. Bank stock prices decline following these changes.

Because bank lending can lead to significant downstream effects on economic growth, the effects on lending that we highlight may have significant economic effects in environments in which bank CEO turnover is frequent. In contrast, these economic effects may be low in environments where bank CEO turnover is infrequent. Moreover, the asymmetric information problems that lead to the effects documented in this study may be minimized in the case of internally promoted bank CEOs. Our data do not allow us to study these questions. Therefore, we suggest these as important questions for further research.

\section{Supplementary Material}

Supplementary Material for this article is available at https://doi.org/10.1017/ S002210901800056X.

\section{References}

Acharya, V., and M. Richardson. Restoring Financial Stability: How to Repair a Failed System. Hoboken, NJ: John Wiley \& Sons (2009a).

Acharya, V. V., and M. Richardson. "Causes of the Financial Crisis." Critical Review, 21 (2009b), 195-210.

Aggarwal, R.; I. Erel; M. Ferreira; and P. Matos. "Does Governance Travel around the World? Evidence from Institutional Investors.” Journal of Financial Economics, 100 (2011), 154-181.

Ahmed, A. S.; B. K. Billings; R. M. Morton; and M. Stanford-Harris. "The Role of Accounting Conservatism in Mitigating Bondholder-Shareholder Conflicts Over Dividend Policy and in Reducing Debt Costs.” Accounting Review, 77 (2002), 867-890.

Amihud, Y., and B. Lev. "Risk Reduction as a Managerial Motive for Conglomerate Mergers." Bell Journal of Economics, 12 (1981), 605-617.

Ashcraft, A. B. "Are Banks Really Special? New Evidence from the FDIC-Induced Failure of Healthy Banks.” Financial Reserve Board of New York Staff Report (Dec. 2003).

Avramov, D.; T. Chordia; G. Jostova; and A. Philipov. "Dispersion in Analysts' Earnings Forecasts and Credit Rating." Journal of Financial Economics, 91 (2009), 83-101.

Banerjee, A.; S. Cole; and E. Duflo. "Are the Monitors Over-Monitored? Evidence from Corruption, Vigilance, and Lending in Indian Banks." Working Paper, Massachusetts Institute of Technology (2008).

Banerjee, A. V., and E. Duflo. "Do Firms Want to Borrow More? Testing Credit Constraints Using a Directed Lending Program.” Review of Economic Studies, 81 (2014), 572-607. 
Bardhan, P. The Political Economy of Development in India: Expanded Edition with an Epilogue on the Political Economy of Reform in India. Uttar Pradesh, India: OUP India (1999).

Barker, V. L. III, and G. C. Mueller. "CEO Characteristics and Firm R\&D Spending." Management Science, 48 (2002), 782-801.

Barron, O. E.; C. O. Kile; and T. B. O'Keefe. "MD\&A Quality as Measured by the SEC and Analysts' Earnings Forecasts." Contemporary Accounting Research, 16 (1999), 75-109.

Barron, O. E., and P. S. Stuerke. "Dispersion in Analysts' Earnings Forecasts as a Measure of Uncertainty." Journal of Accounting, Auditing \& Finance, 13 (1998), 245-270.

Beatty, A.; S. L. Chamberlain; and J. Magliolo. "Managing Financial Reports of Commercial Banks: The Influence of Taxes, Regulatory Capital, and Earnings." Journal of Accounting Research, (1995), 231-261.

Beatty, A., and S. Liao. "Do Delays in Expected Loss Recognition Affect Banks' Willingness to Lend?" Journal of Accounting and Economics, 52 (2011), 1-20.

Beatty, A. L.; B. Ke; and K. R. Petroni. "Earnings Management to Avoid Earnings Declines across Publicly and Privately Held Banks.” Accounting Review, 77 (2002), 547-570.

Beaver, W.; C. Eger; S. Ryan; and M. Wolfson. "Financial Reporting, Supplemental Disclosures, and Bank Share Prices.” Journal of Accounting Research, 27 (1989), 157-178.

Beaver, W. H., and E. E. Engel. "Discretionary Behavior with Respect to Allowances for Loan Losses and the Behavior of Security Prices.” Journal of Accounting and Economics, 22 (1996), 177-206.

Beck, T.; A. Demirgüç-Kunt; and R. Levine. "Financial Institutions and Markets across Countries and over Time:Data and Analysis.” World Bank Policy Research Working Paper Series (2009).

Beck, T.; R. Levine; and A. Levkov. "Big Bad Banks? The Winners and Losers from Bank Deregulation in the United States.” Journal of Finance, 65 (2010), 1637-1667.

Bertrand, M., and S. Mullainathan. "Enjoying the Quiet Life? Corporate Governance and Managerial Preferences." Journal of Political Economy, 111 (2003), 1043-1075.

Bhagwati, J. India in Transition: Freeing the Economy. Uttar Pradesh, India: OUP India (1993).

Bikker, J., and P. Metzemakers. "Is Bank Capital Procyclical? A Cross-Country Analysis.” Working Paper, Netherlands Central Bank (2004).

Brickley, J. A.; J. S. Linck; and J. L. Coles. "What Happens to CEOs after They Retire? New Evidence on Career Concerns, Horizon Problems, and CEO Incentives.” Journal of Financial Economics, 52 (1999), 341-377.

Bruche, M., and G. Llobet. "Preventing Zombie Lending." Review of Financial Studies, 27 (2014), 923-956.

Buchholtz, A. K., and B. A. Ribbens. "Role of Chief Executive Officers in Takeover Resistance: Effects of CEO Incentives and Individual Characteristics." Academy of Management Journal, 37 (1994), 554-579.

Buchholtz, A. K.; B. A. Ribbens; and I. T. Houle. "The Role of Human Capital in Postacquisition CEO Departure.” Academy of Management Journal, 46 (2003), 506-514.

Bushman, R. M., and C. D. Williams. "Accounting Discretion, Loan Loss Provisioning, and Discipline of Banks' Risk-Taking.” Journal of Accounting and Economics, 54 (2012), 1-18.

Caballero, R. J.; T. Hoshi; and A. K. Kashyap. "Zombie Lending and Depressed Restructuring in Japan." American Economic Review, 98 (2008), 1943-1977.

Cetorelli, N., and P. E. Strahan. "Finance as a Barrier to Entry: Bank Competition and Industry Structure in Local U.S. Markets.” Journal of Finance, 61 (2006), 437-461.

Chava, S., and A. Purnanandam. "The Effect of Banking Crisis on Bank-Dependent Borrowers." Journal of Financial Economics, 99 (2011), 116-135.

Cole, S. "Fixing Market Failures or Fixing Elections? Agricultural Credit in India." American Economic Journal: Applied Economics, 1 (2009), 219-250.

Cole, S. A. "Fixing Market Failures or Fixing Elections? Agricultural Credit in India." Working Paper, Harvard Business School (2008).

Collins, J. H.; D. A. Shackelford; and J. M. Wahlen. "Bank Differences in the Coordination of Regulatory Capital, Earnings, and Taxes.” Journal of Accounting Research, 33 (1995), 263-291.

Conyon, M., and A. Florou. "Does Governance Mitigate Horizon Problems?" Working Paper, University of Pennsylvania (2003).

Cornett, M. M.; J. J. McNutt; and H. Tehranian. "Earnings Management at Large U.S. Bank Holding Companies." Working Paper, available at https://ssrn.com/abstract=886115 (2006).

Coughlan, A. T., and R. M. Schmidt. "Executive Compensation, Management Turnover, and Firm Performance: An Empirical Investigation.” Journal of Accounting and Economics, 7 (1985), 43-66.

DeAngelo, H., and L. DeAngelo. "Proxy Contests and the Governance of Publicly Held Corporations." Journal of Financial Economics, 23 (1989), 29-59. 
Dechow, P.; W. Ge; and C. Schrand. "Understanding Earnings Quality: A Review of the Proxies, Their Determinants and Their Consequences." Journal of Accounting and Economics, 50 (2010), 344-401.

Dechow, P. M., and R. G. Sloan. "Executive Incentives and the Horizon Problem: An Empirical Investigation.” Journal of Accounting and Economics, 14 (1991), 51-89.

Demirgüç-Kunt, A., and V. Maksimovic. "Law, Finance, and Firm Growth.” Journal of Finance, 53 (1998), 2107-2137.

Denis, D. J.; D. K. Denis; and A. Sarin. “Ownership Structure and Top Executive Turnover.” Journal of Financial Economics, 45 (1997), 193-221.

Dinç, I. S. "Politicians and Banks: Political Influences on Government-Owned Banks in Emerging Markets." Journal of Financial Economics, 77 (2005), 453-479.

Ecker, F.; J. Francis; I. Kim; P. M. Olsson; and K. Schipper. "A Returns-Based Representation of Earnings Quality.” Accounting Review, 81 (2006), 749-780.

Elliott, J. A.; J. D. Hanna; and W. H. Shaw. "The Evaluation by the Financial Markets of Changes in Bank Loan Loss Reserve Levels.” Accounting Review, (1991), 847-861.

Elliott, J. A., and W. H. Shaw. "Write-Offs as Accounting Procedures to Manage Perceptions." Journal of Accounting Research, 26 (1988), 91-119.

Fahlenbrach, R., and R. M. Stulz. "Bank CEO Incentives and the Credit Crisis." Journal of Financial Economics, 99 (2011), 11-26.

Furfine, C. H. "Banks as Monitors of Other Banks: Evidence from the Overnight Federal Funds Market." Journal of Business, 74 (2001), 33-57.

Gopalan, R.; A. Mukherjee; and M. Singh. "Do Debt Contract Enforcement Costs Affect Financing and Asset Structure?" Review of Financial Studies, 29 (2016), 2774-2813.

Goyal, V. K., and C. W. Park. "Board Leadership Structure and CEO Turnover." Journal of Corporate Finance, 8 (2002), 49-66.

Greenawalt, M. B., and J. F. Sinkey Jr. "Bank Loan-Loss Provisions and the Income-Smoothing Hypothesis: An Empirical Analysis.” Journal of Financial Services Research, 1 (1988), 301-318.

Griffin, P. A., and S. J. Wallach. "Latin American Lending by Major U.S. Banks: The Effects of Disclosures about Nonaccrual Loans and Loan Loss Provisions.” Accounting Review, 66 (1991), 830-846.

Gupta, N. "Partial Privatization and Firm Performance." Journal of Finance, 60 (2005), 987-1015.

Hayes, R. M., and S. Schaefer. "How Much Are Differences in Managerial Ability Worth?" Journal of Accounting and Economics, 27 (1999), 125-148.

Healy, P. M., and J. M. Wahlen. "A Review of the Earnings Management Literature and Its Implications for Standard Setting.” Accounting Horizons, 13 (1999), 365-383.

Hertzberg, A.; J. Liberti; and D. Paravisini. "Information and Incentives Inside the Firm: Evidence from Loan Officer Rotation.” Journal of Finance, 65 (2010), 795-828.

Hoshi, T., and A. K. Kashyap. "Japan's Financial Crisis and Economic Stagnation.” Journal of Economic Perspectives, 18 (2004), 3-26.

Hubbard, R. G., and D. Palia. "Executive Pay and Performance Evidence from the U.S. Banking Industry." Journal of Financial Economics, 39 (1995), 105-130.

Huizinga, H., and L. Laeven. "Bank Valuation and Accounting Discretion during a Financial Crisis." Journal of Financial Economics, 106 (2012), 614-634.

Imhoff, E. A. Jr., and G. J. Lobo. "The Effect of Ex Ante Earnings Uncertainty on Earnings Response Coefficients.” Accounting Review, 67 (1992), 427-439.

Jayaratne, J., and P. E. Strahan. "The Finance-Growth Nexus: Evidence from Bank Branch Deregulation.” Quarterly Journal of Economics, 111 (1996), 639-670.

Jayaratne, J., and P. E. Strahan. "Entry Restrictions, Industry Evolution, and Dynamic Efficiency: Evidence from Commercial Banking." Journal of Law \& Economics, 41 (1998), 239-274.

Jensen, M. C., and C. W. Smith. "Stockholder, Manager, and Creditor Interests: Applications of Agency Theory." In Theory of the Firm: Governance, Residual Claims, and Organizational Forms, Cambridge, MA: Harvard University Press (2000).

Jenter, D., and F. Kanaan. "CEO Turnover and Relative Performance Evaluation.” Journal of Finance, 70 (2015), 2155-2184.

Johnson, W. B.; R. P. Magee; N. J. Nagarajan; and H. A. Newman. "An Analysis of the Stock Price Reaction to Sudden Executive Deaths: Implications for the Managerial Labor Market." Journal of Accounting and Economics, 7 (1985), 151-174.

Khwaja, A. I., and A. Mian. "Do Lenders Favor Politically Connected Firms? Rent Provision in an Emerging Financial Market.” Quarterly Journal of Economics, 120 (2005), 1371-1411.

Kilic, E.; G. J. Lobo; T. Ranasinghe; and K. Sivaramakrishnan. "The Impact of SFAS 133 on Income Smoothing by Banks through Loan Loss Provisions.” Accounting Review, 88 (2012), 233-260. 
Kim, J. "Additional Evidence on Relative Performance Evaluation Hypothesis." Working Paper, Carnegie Mellon University (1996).

Kim, M.-S., and W. Kross. "The Impact of the 1989 Change in Bank Capital Standards on Loan Loss Provisions and Loan Write-Offs.” Journal of Accounting and Economics, 25 (1998), 69-99.

King, R. G., and R. Levine. "Finance and Growth: Schumpeter Might Be Right." Quarterly Journal of Economics, 108 (1993), 717-737.

Laeven, L., and G. Majnoni. "Loan Loss Provisioning and Economic Slowdowns: Too Much, Too Late?" Journal of Financial Intermediation, 12 (2003), 178-197.

Le Breton-Miller, I., and D. Miller. "Why Do Some Family Businesses Out-Compete? Governance, Long-Term Orientations, and Sustainable Capability." Entrepreneurship Theory and Practice, 30 (2006), 731-746.

Liebersohn, C. J. "The Cyclicality of Executive Turnover." Working Paper, available at https://papers .ssrn.com/sol3/papers.cfm?abstract_id=2584705 (2015).

Lilienfeld-Toal, U. V.; D. Mookherjee; and S. Visaria. "The Distributive Impact of Reforms in Credit Enforcement: Evidence from Indian Debt Recovery Tribunals.” Econometrica, 80 (2012), 497-558.

Liu, C.-C., and S. G. Ryan. "Income Smoothing over the Business Cycle: Changes in Banks' Coordinated Management of Provisions for Loan Losses and Loan Charge-Offs from the Pre-1990 Bust to the 1990s Boom." Accounting Review, 81 (2006), 421-441.

Mannix, E. A., and G. F. Loewenstein. "The Effects of Interfirm Mobility and Individual versus Group Decision Making on Managerial Time Horizons." Organizational Behavior and Human Decision Processes, 59 (1994), 371-390.

Morgan, D. P. "Rating Banks: Risk and Uncertainty in an Opaque Industry." American Economic Review, 92 (2002), 874-888.

Morgan, D. P., and K. J. Stiroh. "Market Discipline of Banks: The Asset Test.” Journal of Financial Services Research, 20 (2001), 195-208.

Moyer, S. E. "Capital Adequacy Ratio Regulations and Accounting Choices in Commercial Banks." Journal of Accounting and Economics, 13 (1990), 123-154.

Murphy, K. J., and J. L. Zimmerman. "Financial Performance Surrounding CEO Turnover." Journal of Accounting and Economics, 16 (1993), 273-315.

Myers, S. C., and N. S. Majluf. "Corporate Financing and Investment Decisions When Firms Have Information That Investors Do Not Have." Journal of Financial Economics, 13 (1984), 187-221.

Myers, S. C., and R. G. Rajan. "The Paradox of Liquidity." Quarterly Journal of Economics, 113 (1998), 733-771.

Parrino, R. "CEO Turnover and Outside Succession: A Cross-Sectional Analysis." Journal of Financial Economics, 46 (1997), 165-197.

Peek, J., and E. S. Rosengren. "Unnatural Selection: Perverse Incentives and the Misallocation of Credit in Japan." American Economic Review, 95 (2005), 1144-1166.

Pourciau, S. "Earnings Management and Nonroutine Executive Changes." Journal of Accounting and Economics, 16 (1993), 317-336.

Rajan, R. G., and L. Zingales. "Financial Dependence and Growth." American Economic Review, 88 (1998), 559-586.

Rogoff, K. S. "Moral Hazard in IMF Loans: How Big a Concern?" Finance and Development, 39 (2002), 56-57.

Salas, J. M. "Entrenchment, Governance, and the Stock Price Reaction to Sudden Executive Deaths." Journal of Banking \& Finance, 34 (2010), 656-666.

Sapienza, P. "The Effects of Government Ownership on Bank Lending." Journal of Financial Economics, 72 (2004), 357-384.

Scholes, M. S.; G. P. Wilson; and M. A. Wolfson. "Tax Planning, Regulatory Capital Planning, and Financial Reporting Strategy for Commercial Banks.” Review of Financial Studies, 3 (1990), 625-650.

Schwartz-Ziv, M., and M. S. Weisbach. "What Do Boards Really Do? Evidence from Minutes of Board Meetings.” Journal of Financial Economics, 108 (2013), 349-366.

Stein, J. C. "Information Production and Capital Allocation: Decentralized versus Hierarchical Firms." Journal of Finance, 57 (2002), 1891-1921.

Strong, J. S., and J. R. Meyer. "Asset Writedowns: Managerial Incentives and Security Returns." Journal of Finance, 42 (1987), 643-661.

Taylor, J. B. "The Financial Crisis and the Policy Responses: An Empirical Analysis of What Went Wrong." Working Paper, National Bureau of Economic Research (2009).

Teoh, S. H., and T. Wong. "Perceived Auditor Quality and the Earnings Response Coefficient." Accounting Review, 68 (1993), 346-366. 


\section{Journal of Financial and Quantitative Analysis}

Tzioumis, K., and M. Gee. "Nonlinear Incentives and Mortgage Officers' Decisions." Journal of Financial Economics, 107 (2013), 436-453.

Vig, V. "Access to Collateral and Corporate Debt Structure: Evidence from a Natural Experiment." Journal of Finance, 68 (2013), 881-928.

Visaria, S. "Legal Reform and Loan Repayment: The Microeconomic Impact of Debt Recovery Tribunals in India." American Economic Journal: Applied Economics, 1 (2009), 59-81.

Wahlen, J. M. "The Nature of Information in Commercial Bank Loan Loss Disclosures." Accounting Review, 69 (1994), 455-478.

Warner, J. B.; R. L. Watts; and K. H. Wruck. "Stock Prices and Top Management Changes." Journal of Financial Economics, 20 (1988), 461-492.

Weisbach, M. S. "Outside Directors and CEO Turnover." Journal of Financial Economics, 20 (1988), 431-460.

Zhang, X. "Information Uncertainty and Stock Returns." Journal of Finance, 61 (2006), 105-137. 